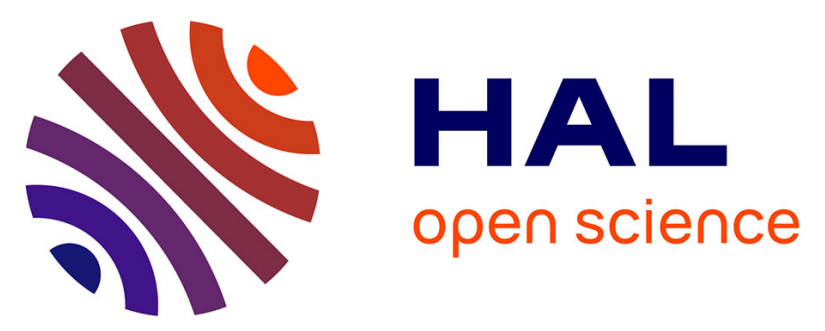

\title{
Geochemical signature of sources, recycling and weathering in the Last Glacial loess from the Rhône Valley (southeast France) and comparison with other European regions
}

Mathieu Bosq, Pascal Bertran, Jean-Philippe Degeai, Alain Queffelec, Olivier Moine

\section{To cite this version:}

Mathieu Bosq, Pascal Bertran, Jean-Philippe Degeai, Alain Queffelec, Olivier Moine. Geochemical signature of sources, recycling and weathering in the Last Glacial loess from the Rhône Valley (southeast France) and comparison with other European regions. Aeolian Research, 2020, 42, pp.100561. 10.1016/j.aeolia.2019.100561 . hal-02440380v2

\section{HAL Id: hal-02440380 \\ https://hal.science/hal-02440380v2}

Submitted on 11 Jun 2020

HAL is a multi-disciplinary open access archive for the deposit and dissemination of scientific research documents, whether they are published or not. The documents may come from teaching and research institutions in France or abroad, or from public or private research centers.
L'archive ouverte pluridisciplinaire HAL, est destinée au dépôt et à la diffusion de documents scientifiques de niveau recherche, publiés ou non, émanant des établissements d'enseignement et de recherche français ou étrangers, des laboratoires publics ou privés. 


\title{
Geochemical signature of sources, recycling and weathering in the Last Glacial loess from the Rhône Valley (southeast France) and comparison with other European regions
}

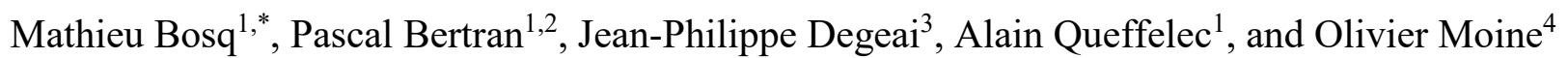 \\ ${ }^{1}$ PACEA, UMR 5199 CNRS - Université Bordeaux, Bâtiment B2, allée Geoffroy Saint Hilaire, 33615 \\ Pessac, France \\ ${ }^{2}$ Inrap, 140 avenue du Maréchal Leclerc, 33130 Bègles, France \\ ${ }^{3}$ ASM, UMR 5140 CNRS - Université de Montpellier III, route de Mende, 34199 Montpellier, France \\ ${ }^{4}$ LGP, UMR 8591 CNRS - Université Paris I Panthéon-Sorbonne/Université Paris-Est-Créteil-Val- \\ de-Marne (UPEC), place Aristide Briand, 92195 Meudon, France
}

*Corresponding author: Mathieu Bosq (mathieu.bosq@,gmail.com)

\begin{abstract}
Pleistocene loess of the Rhône Valley and Provence region, disconnected from the two main European aeolian systems (North European Loess Belt and Danube basin), are of interest to test the impact of source variability, grain size sorting, weathering and sediment recycling on the geochemical composition. The concentration of major, trace and rare earth elements in loess and potential sources was analysed through Inductively Coupled Plasma-Atomic Emission Spectroscopy (ICP-AES) and ICP-Mass Spectometry (ICP-MS). Analyses show a genetic relationship between loess and the Ca-rich river sediments from the Alpine Ice Sheet (AIS). The loess of Provence show distinctive properties with a higher $\mathrm{CaO}$ and $\mathrm{MgO}$ content and a higher Europium anomaly ( $\left.\mathrm{Eu} / \mathrm{Eu}^{*}\right)$, suggesting sources richer in dolomite together with a contribution from mafic rocks (Alpine ophiolite complex). The homogeneous loess composition, compared to alluvial sources, reflects particle mixing during transport in the atmosphere. At the European scale, the geochemical composition of loess changes according to regions, but remains consistent within each region. Such variability is mostly related to the composition of rocks outcropping in respective catchments and especially in areas covered by ice sheets. The Chemical Proxy of Alteration (CPA) and $\mathrm{Rb} / \mathrm{K}$ ratio suggest a weak chemical weathering linked to the cold and dry conditions typical of the Last Glacial. Recycling of older aeolian formations possibly caused loess enrichment in resistant minerals and quartz, especially for loess derived mostly from the abrasion of aeolian sand (Aquitaine).
\end{abstract}

Keywords: Geochemistry; ICP analysis; Last Glacial; Loess; Southeast France; Weathering

\section{Introduction}

Loess/palaeosol sequences provide one of the most complete record of terrestrial palaeoenvironments during the Pleistocene and, as such, have raised abundant work worldwide for decades (e.g., Antoine et al., 2013, 2009; Kukla, 1977; Marković et al., 2015; Muhs and Bettis III, 2003; Porter, 2001). Thanks to thorough mixing in the atmosphere, loess is quite homogeneous and is widely distributed across continents. This led many authors to use it together with other sedimentary rocks to estimate the Upper 
Continental Crust (UCC) average geochemical composition (Chauvel et al., 2014; Gallet et al., 1998; McLennan, 2001; Taylor et al., 1983; Taylor and McLennan, 1985). Recent studies, however, emphasized that the geochemical composition of loess differs significantly according to the region and is more dependent on local sources than previously assumed (Muhs and Bettis III, 2003; Muhs and Budahn, 2006; Rousseau et al., 2014; Schatz et al., 2015; Sun et al., 2007). Recycling of older aeolian sediments, grain-size sorting due to fluvial transport and syn-sedimentary weathering may also constitute key factors accounting for observed variations (Buggle et al., 2008; Gallet et al., 1998; Lautridou et al., 1984; Újvári et al., 2008). Therefore, a debate persists about the respective roles played by genetic factors on loess composition.

Most geochemical studies focused on the main loess regions from the northern hemisphere, including the North European Loess Belt (NELB), China and the United States of America. Because of their sparser accumulation in the landscape, perimediterranean loess remain poorly documented except for some exceptions (Calvo et al., 2016; Profe et al., 2018). Recent studies in the Po plain (Wacha et al., 2018) the Ebro (Boixadera et al., 2015) and Tagus basins (Wolf et al., 2019) in Spain suggested, however, that Pleistocene loess covered vast parts of perimediterranean areas. The Rhône Valley (SE France) also recorded significant loess deposition during the Last Glacial (Bosq et al., 2018). As suggested by models (Mahowald et al., 2006), part of the dust inputs to this region may have come from remote sources such as the Sahara. Saharan sources are also thought to have largely contributed to the genesis of "Terra Rossa" and "Red Mediterranean Soils" (Andreucci et al., 2012; Muhs et al., 2010), which are widespread in the southern reaches of the valley. Because of a contrasted relief and the variety of potential sources, the Rhône Valley is ideal to unravel the role of the different contributing factors on the geochemical composition of loess and will be the focus of this study.

Here we present new geochemical analyses of loess samples from the Rhône Valley. Main objectives are as follow: (1) a detailed characterization of loess geochemistry; (2) the identification of regional and remote (Saharan) sources; (3) a comparison with loess from other European regions through recently collected samples and literature. Overall, this study provides a better understanding of the role played by source variability, weathering and sediment recycling in the loess geochemical signature.

\section{Regional setting}

\subsection{Geological and climate setting}

The Rhône River is one of the largest European Rivers (catchment area $=98,500 \mathrm{~km}^{2}$, mean annual discharge $=1720 \mathrm{~m}^{3}$ ) (Eyrolle et al., 2012; Olivier et al., 2009) and drains most of Switzerland and southeastern France toward the Mediterranean Sea (Fig. 1a). The valley is part of a large Cenozoic Rift System running throughout Western Europe from the North Sea to the Mediterranean Sea (Dèzes et al., 2004; Ziegler and Dèzes, 2007). The river catchment includes Hercynian mountain ranges mainly composed of metamorphic and plutonic rocks (French Massif Central (FMC), Vosges, Belledonne) as well as Alpine ranges (Alps, Jura), dominated by Mesozoic to Cenozoic limestones and marls. The graben was filled with Oligocene and Miocene marls, argillites and sandstones (molasses) and conglomerates (Fig. 1a). The Alpine Ice Sheet (AIS) reconstructions indicate that an ice lobe covered the Dombes plateau and crossed the Rhône River during the Middle Pleistocene (Buoncristiani and Campy, 2011; Ehlers and Gibbard, 2004). The AIS extent during the Last Glacial Maximum (LGM) was smaller and limited to the eastern edge of the Rhône Valley (Seguinot et al., 2018). Only minor LGM ice caps covered the FMC and the Vosges (Fig. 1) (Ehlers and Gibbard, 2004).

The Rhône Valley is subject to changing climate conditions from an oceanic climate characterized by high precipitation (mean annual precipitation (MAP) $\geq 800-900 \mathrm{~mm}$ ) in the northern lowlands to a Mediterranean climate in the south with $\mathrm{MAP}<800 \mathrm{~mm}$, hot $\left(\operatorname{Tmax} \geq 22^{\circ} \mathrm{C}\right)$ and dry summers (Joly et 
al., 2010; Olivier et al., 2009). The wind regime is dominated by the "Mistral", blowing from the north and exceeding $16 \mathrm{~m} . \mathrm{s}^{-1}$ for over 100 days per year (Jacq et al., 2005).
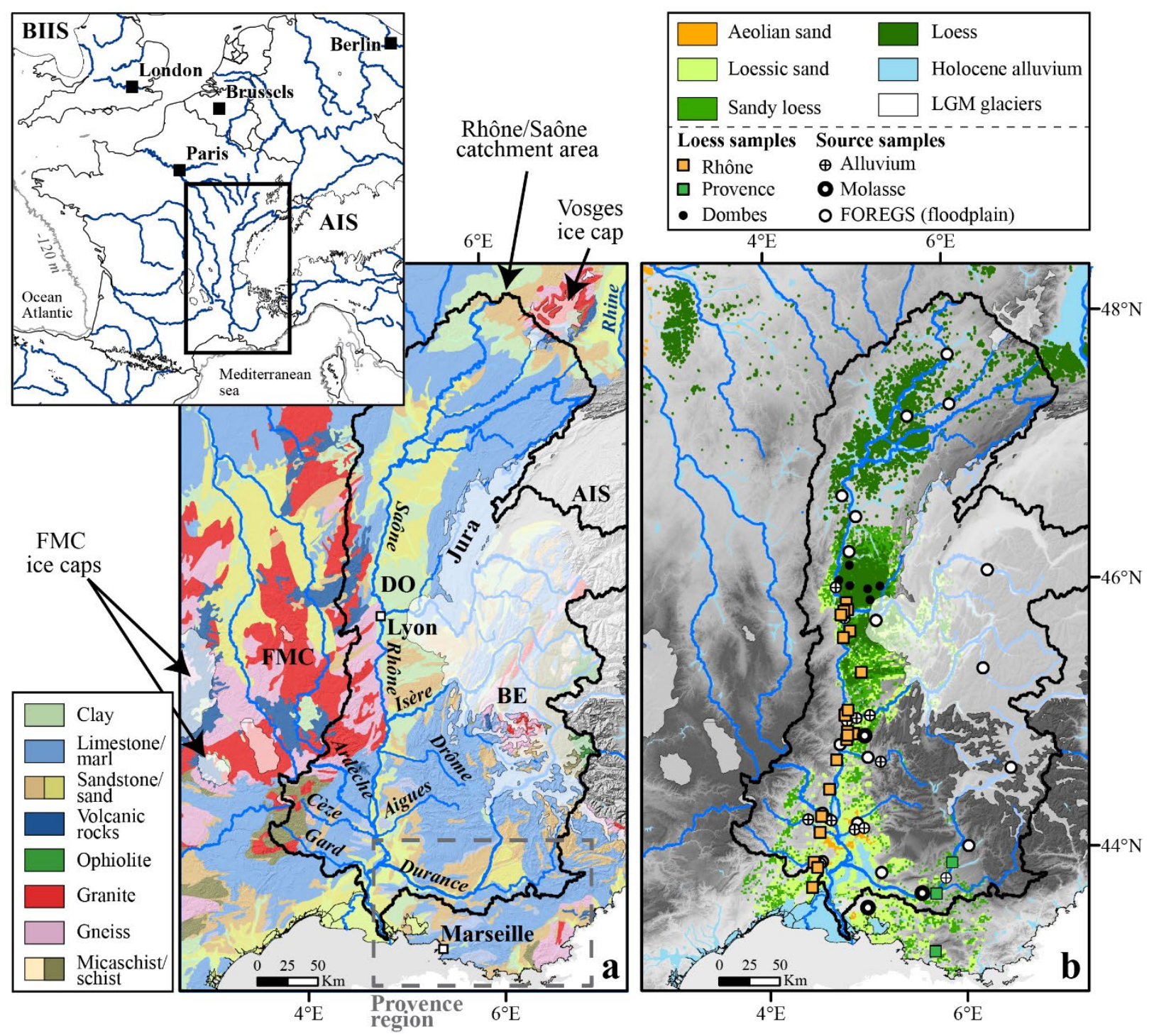

Fig. 1: (a) Simplified 1:1,000,000 lithological map of southeast France (from BRGM, http://infoterre.brgm.fr). The maximum extent of the LGM Alpine Ice Sheet (AIS), the French Massif Central (FMC) and Vosges ice caps is taken from Ehlers and Gibbard (2004). The red square indicates the approximate boundaries of the Provence region. BIIS $=$ British-Irish Ice Sheet; DO = Dombes plateau; BE = Belledonne massif. (b) Distribution of aeolian deposits from Bosq et al. (2018). All the samples of loess and potential sources come from the FOREGS database (Salminen et al., 2005); data from new field surveys are indicated (see Table A1).

\subsection{Aeolian context}

Aeolian landforms and deposits are widespread along the lower reaches of the valley (Bosq et al., 2018). Deflation-related landforms (i.e., yardangs, pans and desert pavements) are gathered south of valley narrowings (e.g., the "Donzère pass" near Montélimar), which channel and increase wind velocity. These landforms closely resemble those observed in modern semi-arid and arid environments (Goudie, 2013) and witness important sand transport by saltation over vast areas. Sand wedges forming polygon networks also developed over Pleistocene alluvial terraces. These features are indicative of 
ground cracking caused by repetitive thermal contraction in a context of deep seasonal freezing, which allowed trapping of drifting sand (Andrieux et al., 2016). Yardang orientations and sand accumulation on the windward and leeward slopes of topographic highs form sand ramps testifying to a prevailing northerly palaeowind similar to the modern Mistral.

Loess deposits are spread on both sides of the valley at greater distance from the river. A detailed geomorphological study by Bosq et al. (2018) has highlighted the following characteristics of loess: (i) a coarse texture (main mode around $60 \mu \mathrm{m}$ ) rapidly decreasing with increasing distance from the river; (ii) a polymodal grain-size distribution; (iii) a strong local thickness but discontinuous spatial distribution; (iv) a high carbonate content; (v) an abundant bioturbation. Such pattern was assumed $\mathrm{t}$ reflect the capture of particles in saltation and short-term suspension by shrub vegetation close to the fluvial sources, in a milder climate than that of the NELB (Bosq et al., 2018). The spatial distribution of aeolian deposits strongly suggests that the Rhône River and its tributaries were the main particle sources (Bosq et al., 2018). Old alluvial terraces as well as unconsolidated molasses eroded into yardangs and pans might have constituted additional sources.

Alimen (1965) and Dubar (1979) performed pioneer mineralogical studies in the Durance Valley, one of the main Rhône River Alpine tributaries. Using heavy mineral assemblages, the authors suggested that dust came mostly from proximal alluvial deposits of the Alpine piedmont. Similarly, Mandier (1984) found Alpine heavy minerals in loess from the middle Rhône Valley. Recently, Puaud et al. (2015) identified volcanic minerals from the FMC mixed with typical Alpine minerals in loess from the Ardèche Valley. However, these studies remain scarce and are not sufficient to identify dust sources (either local, regional or more remote such as the Sahara) and their respective contribution.

\section{Materials and methods}

\subsection{Sampling and analytical methods}

We collected 28 loess samples from natural outcrops, archaeological excavations, roadcuts and abandoned pits. Prior to sampling, sections were manually cleaned and thoroughly described. All loess samples were taken below the Holocene soil. We focused only on the uppermost massive yellowish calcareous loess, 2 to $4 \mathrm{~m}$ thick, which was deposited during the Late Pleniglacial, i.e., $\sim$ Marine Isotopic Stage (MIS) 2 (Bosq et al., 2018; Ruth et al., 2007; Seelos et al., 2009) although the possibility of older deposits cannot be completely ruled out for non-dated sequences. Five samples come from reddish palaeosols interbedded within calcareous loess. Decalcified and clay-rich loess samples $(\mathrm{n}=$ 7) probably dating from MIS 6 (Billard and Derbyshire, 1985) were collected on the Dombes plateau using a hand auger owing to the lack of good outcrops in this area. Following the source tracing approach developed by Muhs and Budahn (2006), modern alluvium from the floodplain and silt-rich alluvial bars were sampled. A total of 15 samples were taken along the Rhône River $(n=4)$ and the main tributaries, Saône $(n=1)$, Isère $(n=2)$, Drôme $(n=1)$, Durance $(n=1)$, Aigues $(n=1)$, Cèze $(n$ $=1)$, Ouvèze $(n=1)$, Ardèche $(n=1)$, Gard $(n=1)$ and Doux $(n=1)$. Finally, three samples from the Miocene molasses were also collected (Fig. 1b).

Coarser sand was separated from the fraction $<100 \mu \mathrm{m}$ by wet sieving and removed. We assumed that the particles $>100 \mu \mathrm{m}$, which account for 1 to $20 \%$ of the net weight, are mostly made of ferruginous nodules, secondary carbonate concretions, calcified roots, mollusc shell fragments, earthworm calcite granules or detrital particles transported by runoff that could conceal the aeolian signature. According to Bosq et al. (2018), all loess samples have a polymodal grain-size distribution with a main mode between 50 and $75 \mu \mathrm{m}(63 \pm 9 \%)$ and a secondary mode around $12-18 \mu \mathrm{m}(25 \pm 8 \%)$. Given that the grain-size fractions of loess reflect different transport processes or different sources (Pye, 1995; Tsoar and Pye, 1987), we divided the samples by wet sieving into a fine fraction $32 \mu \mathrm{m}$ and a coarse fraction 
from 32 to $100 \mu \mathrm{m}$. We chose a limit at $32 \mu \mathrm{m}$ since it is the adequate for the separation of the two main modes. For selected loess samples $(n=2)$ and reddish palaeosols $(n=3)$, the fraction $<10 \mu \mathrm{m}$ was isolated by gravity sedimentation in water using Stokes Law and checked by laser diffraction particle-sizing. For alluvial samples, the fraction $100 \mu \mathrm{m}$ was analysed as a whole.

Concentrations (weight percentage or ppm) of major, trace and rare earth elements (REEs) for two grain-size fractions $(<32$ and 32-100 $\mu \mathrm{m})$ of loess and palaeosols $(\mathrm{n}=66)$, and for one fraction $(<100$ $\mu \mathrm{m})$ of sources $(\mathrm{n}=18)$, were determined respectively by Inductively Coupled Plasma-Atomic Emission Spectroscopy (ICP-AES) and ICP-Mass Spectometry (ICP-MS) at the Service d'Analyse des Roches et des Minéraux (CRPG-SARM, Nancy, France). Sediment powders were digested with $\mathrm{LiBO}_{2}$, dissolved with $\mathrm{HNO}_{3}$, analysed and calibrated according to international geostandards. The Loss On Ignition (LOI) was obtained by calcination of a sample aliquot (100-1000 mg) placed in an alumina crucible in an oven at $980^{\circ} \mathrm{C}$ during $12 \mathrm{~h}$. Details on the chemical analyses can be found in Carignan et al. (2001) and on the CRPG-SARM website (http://helium.crpg.cnrsnancy.fr/SARM/index.html). For aeolian deposits, the geochemical composition of the whole fraction $<100 \mu \mathrm{m}$ was obtained from the composition of the two fractions considering their respective proportions determined through grain-size analysis. Additional samples $(n=14)$ were analysed by Energy-Dispersive X-Ray Fluorescence (ED-XRF) using a portable spectrometer SPECTRO X-SORT $(40 \mathrm{kV}, 50 \mu \mathrm{A})$ according to published methodology (Bertran et al., 2016; Sitzia et al., 2019) (see Fig. A1). Beside samples from the Rhône Valley, the fraction $<100 \mu \mathrm{m}$ of European loess were also analysed by ICP-AES/ICP-MS (CRPG-SARM, Nancy, France) from northern France $(\mathrm{n}=13)$, Aquitaine (France; $n=3$ ), Rhine Valley (France and Germany; $n=5$ ), Saxony (Germany; $n=2$ ), Belgium $(n=1)$, southern Poland/Ukraine $(n=3)$ and Vojvodina/Balkan (Serbia; $n=1)$. All samples are issued from Upper Pleniglacial loess. All analyses are listed in Tables A1 and A2 in the supporting information.

The coarser fraction of few selected samples $(n=4)$ was also analysed through Raman spectroscopy with a confocal Raman microspectrometer SENTERRA (Bruker Optics) equipped with a $532 \mathrm{~nm}$ excitation line. The spectra were recorded between 100 and $1555 \mathrm{~cm}^{-1}$ with a resolution of $3-5 \mathrm{~cm}^{-1}$ (Fig. A2) and compared to the Rruff database (Lafuente et al., 2016). One hundred grains per sample were counted; results are expressed as percentages.

\subsection{Statistical analysis and weathering proxy}

A multivariate analysis was carried out using Aitchison and Greenacre (2002) methodology for compositional data, which uses the centred log-ratios (clr)-transformed values instead of raw percentages. We used non-parametric replacement of null values according to the method proposed by Martín-Fernández et al. (2003) for values below the detection limit. All the compositional data were analysed using the CoDaPack software (Comas and Thió-Henestrosa, 2011).

Silicate weathering intensity was quantified using the Chemical Proxy of Alteration (CPA) (the molar ratio $\left.100 \times \mathrm{Al}_{2} \mathrm{O}_{3} /\left(\mathrm{Al}_{2} \mathrm{O}_{3}+\mathrm{Na}_{2} \mathrm{O}\right)\right)(\mathrm{Cullers}, 2000)$ as it is considered a proxy for plagioclase weathering intensity by Buggle et al. (2011). As opposed to commonly used weathering indices in loess studies such as the Chemical Index of Alteration (CIA) (Nesbitt and Young, 1982), CPA does not involve silicate-bounded $\mathrm{Ca}\left(\mathrm{CaO}^{*}\right)$ that is difficult to estimate in calcareous loess. Harnois (1988) also recommended not using $\mathrm{K}$ in weathering index because of $\mathrm{K}$ incorporation in clayey minerals (illitization) and the strong resistance of K-feldspars. Buggle et al. (2011) evaluated the CPA and concluded that diagenetic effects, such as illitization and carbonate dissolution-reprecipitation, have no influence on the index.

\subsection{Literature data}


We selected and compiled part of the literature data on the European loess geochemistry, using samples from the main loess sedimentation period ( MIS 2) only. Geochemical data for floodplain sediments from the Rhône catchment $(\mathrm{n}=17)$ available from the FOREGS project (Salminen et al., 2005) were also included in the analysis (Table A3). To evaluate the contribution of main rock types outcropping in mountain ranges, we compiled literature data on (i) FMC and Vosges igneous and metamorphic rocks (Altherr et al., 2000; Couzinié et al., 2017; Steinmann and Stille, 2008); (ii) oceanic crust (Manatschal et al., 2011), limestones (Bellanca et al., 1997) and shales (Rantitsch et al., 2003) from the Alps; (iii) FMC volcanic rocks (Sasco et al., 2017) and (iv) subalpine sandstones (von Eynatten, 2003).

We also used the compilation of North African dust compositional data from Scheuvens et al. (2013) . Twelve samples representative of the Bodélé depression (Chad), Tarfaya (Western Sahara, Morocco), Hoggar Massif (Algeria) and Niger were selected from the available data (Castillo et al., 2008; Moreno et al., 2006).

Soil geochemical data were collected from the Geochemical Mapping of Agricultural Soils (GEMAS) database (Reimann et al., 2014). We used only samples from the ploughed soil layer (Ap horizon, 0$20 \mathrm{~cm}$ ) analysed by Wavelength Dispersive X-Ray Fluorescence spectrometry (WD-XRFs), which were thought to be of better quality than those obtained using the Aqua Regia extraction protocol coupled with ICP-AES (Reimann et al., 2014).

All spatial analyses were made using ArcGIS 10.5 (ESRI). Modern river catchment limits were obtained from the HydroBASINS polygon layer of the HydroSHEDS database (Lehner and Grill, 2013); http://www.hydrosheds.org). The LGM catchment of the Fleuve Manche (i.e. the palaeoEnglish Channel) and associated river network comes from Patton et al. (2017). Geological data were taken from the harmonized geological map of Europe (INSPIRE, scale 1:1,000,000) (Laxton et al., 2010); http://onegeology.brgm.fr/OnegeologyGlobal/) and completed by the International Geological Map of Europe and Adjacent Areas (IGME 5000, scale 1:5,000,000) (Asch, 2003; https://www.bgr.bund.de/). 

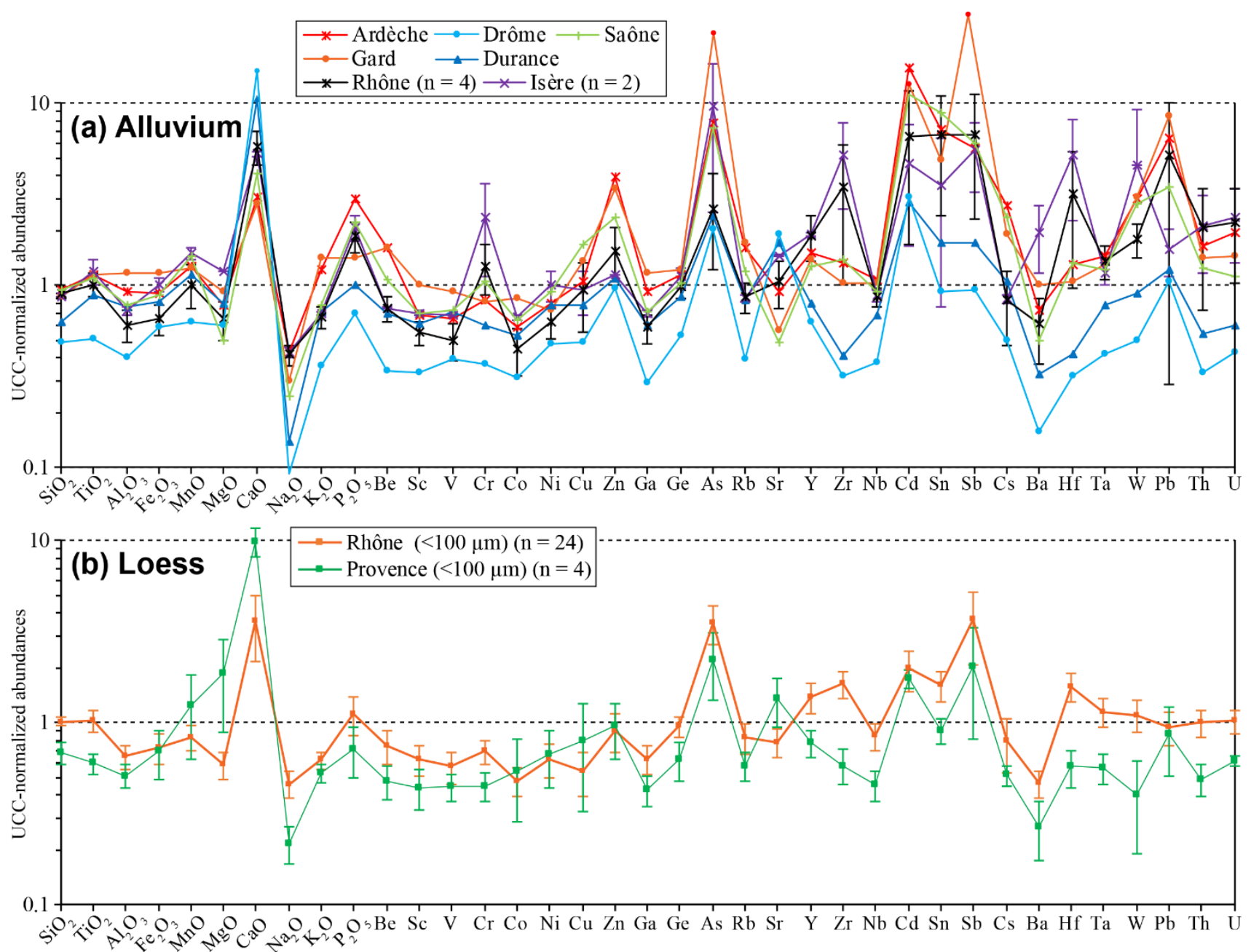

Fig. 2: UCC-normalized spider diagrams for average element abundance of alluvium samples (finer fraction $<100 \mu \mathrm{m}$ ) from the major rivers of the study area (a) and of loess samples from the Rhône and the Provence regions (b). Error bars represent the standard deviation. The UCC values are from Rudnick and Gao (2003).

\section{Results}

\subsection{Major and trace elements in loess and potential sources}

The distribution of major and trace elements is shown in the UCC-normalized spidergrams (Fig. 2). The geochemical composition of alluvial deposits from main rivers shows strong variability with respect to UCC, especially for trace elements (Fig. 2b). A comparison between the geochemical signature of Alpine Rivers (Drôme, Durance, Isère) and that of FMC Rivers (Ardèche, Gard) highlights the following differences: (1) the most calcareous sediments (by about 10 times that of UCC) come from the Alps; (2) a greater abundance of K-bearing minerals, which are major hosts of $\mathrm{Rb}, \mathrm{Cs}$ and $\mathrm{Ba}$ (Gallet et al., 1998; Heier and Billings, 1970), characterizes the sediments delivered by the FMC mainly composed of Hercynian felsic rocks (granite, gneiss); (3) in contrast, Alpine sediments are depleted in $\mathrm{Na}_{2} \mathrm{O}$ and $\mathrm{K}_{2} \mathrm{O}$ relatively to UCC (more than 14 times less $\mathrm{NaO}_{2}$ and 2.7 times less $\mathrm{K}_{2} \mathrm{O}$ considering extreme values); (4) the slight positive $\mathrm{Cr}$ anomaly (on average about twice as much as UCC) and the relatively high Ni content of Isère sediments is due to the contribution of mafic rocks; (5) the elements typically hosted in resistant heavy minerals ( $\mathrm{Zr}, \mathrm{Hf}, \mathrm{Y}, \mathrm{Th}, \mathrm{U}$ ) are mainly found in the Rhône and Isère deposits. Such differences reflect the lithological heterogeneities of catchments. In 
rivers draining the Hercynian FMC and Belledonne massif (western Alps), As and Sb concentrations are unusually high and likely come from sulphide-rich mineralizations such as arsenopyrite (FeAsS) and stibinite $\left(\mathrm{Sb}_{2} \mathrm{~S}_{3}\right)$ (Courtin-Nomade et al., 2012; Simeon, 1979).

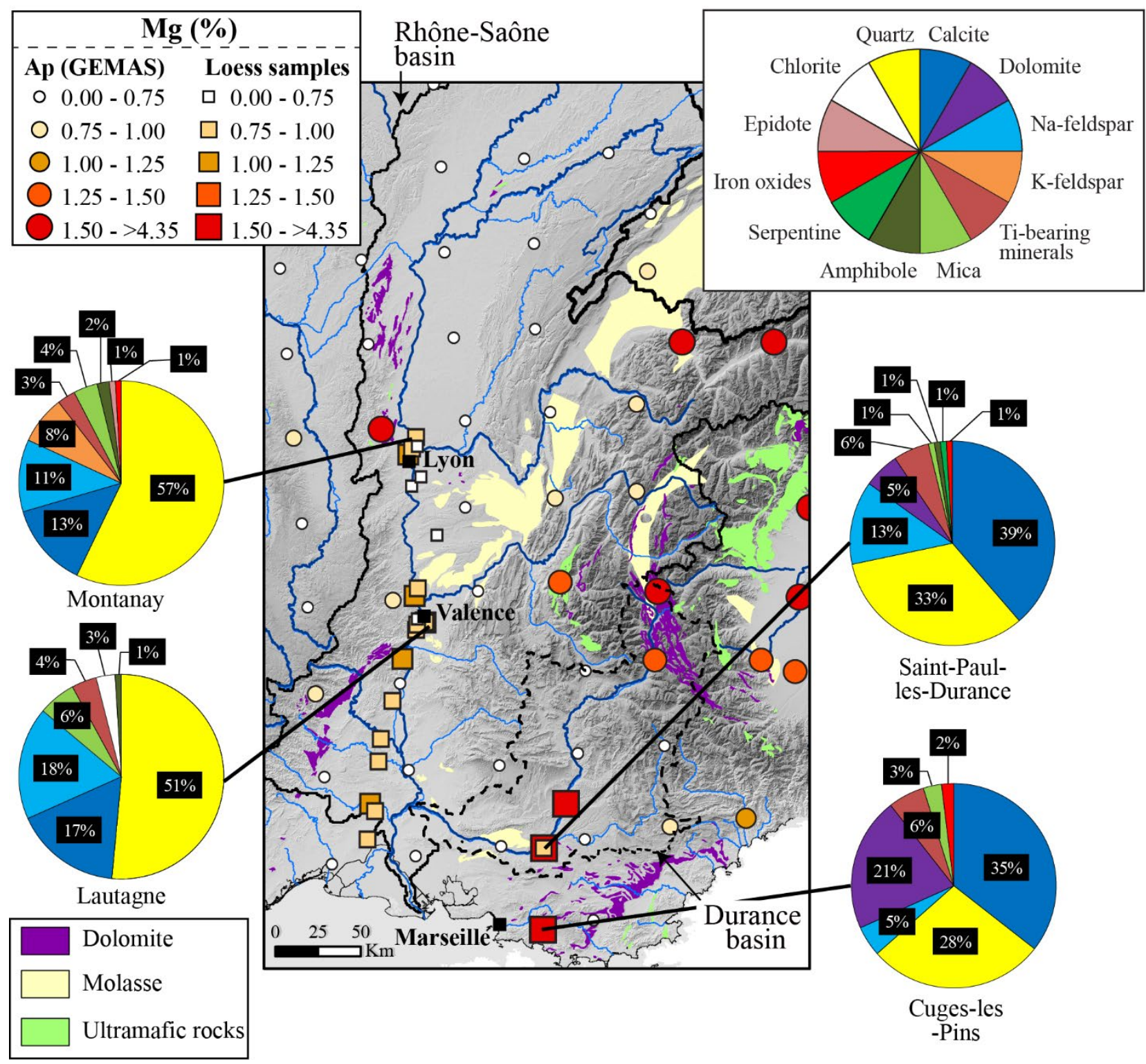

Fig. 3: Map of Mg content (expressed as a percentage) in loess samples and the ploughed soil layer, i.e., Ap horizon from GEMAS database (Reimann et al., 2014). Mineral assemblages and concentrations of the reference samples were analysed by Raman spectroscopy. The geological data were taken from the 1:1,000,000 harmonized geological map of Europe (INSPIRE) (Laxton et al. (2010) and the 1:5,000,000 International Geological Map of Europe (IGME) (Asch, 2003).

Loess are more homogeneous than alluvial deposits (Fig. 2b). The average concentration of selected major and trace elements in loess (fraction $<100 \mu \mathrm{m}$ ), sampled along the Rhône River (RL) and in the Provence region (PL) differs only slightly. For most elements, PL records a depletion relative to UCC due to carbonate dilution effect (Taylor et al., 1983). The $\mathrm{CaO}$ and to a lesser extent $\mathrm{MgO}$ and $\mathrm{Sr}$ (which substitutes $\mathrm{Ca}$ in minerals) contents are substantially higher in loess compared to UCC (by about 10 times for $\mathrm{CaO}$ ). As expected, the mineralogical analysis shows that $\mathrm{CaO}$ comes mostly from calcite (35-39 \%) and dolomite (5-21 \%) (Fig. 3). Compared to RL we observe an enrichment in some 
elements such as Mn, abundant in mafic rocks (e.g., basalt) and to a lesser extent, in manganese-rich shales, commonly found in the calcareous subalpine ranges (Rantitsch et al., 2003). Other siderophile elements (Co, Ni, $\mathrm{Cu}$ and $\mathrm{Zn}$ ) show a similar pattern. Several elements (Ti, Y, Zr, Hf) are slightly more abundant in RL and reflect higher content of resistant heavy minerals.

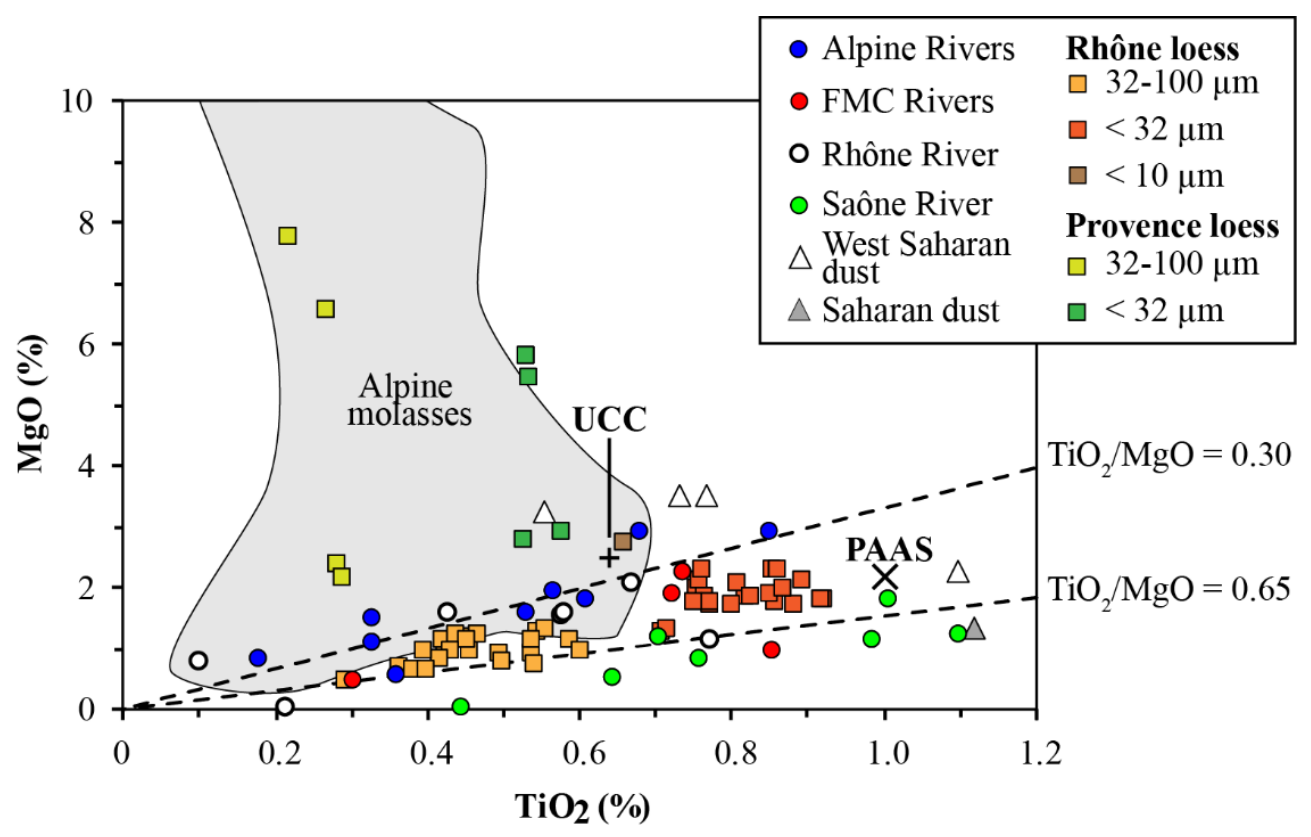

Fig. 4: $\mathrm{MgO}$ vs. $\mathrm{TiO}_{2}$ plot of loess from the Rhône catchment area (Provence and Rhône) and from the potential source deposits. The UCC and PAAS values are from Rudnick and Gao (2003) and Condie (1993). Sources: sandstones from the Central Alps ("Alpine molasses", $n=39$ ) (von Eynatten, 2003); rivers from this study and "Floodplain sediment" in FOREGS database (Salminen et al., 2005); Saharan dusts (Castillo et al., 2008; Moreno et al., 2006).

Higher $\mathrm{MgO}$ content in $\mathrm{PL}$ is linked to a source specific to Provence. In the $\mathrm{MgO}$ vs. $\mathrm{TiO}_{2}$ diagram (Fig. 4), RL and PL samples cluster in two groups. For RL, $\mathrm{MgO}$ covaries with $\mathrm{TiO}_{2}$ and this highly significant relationship $\left(\mathrm{r}^{2}=0.81\right)$ suggests that $\mathrm{MgO}$ is mainly associated with phyllosilicates. The $\mathrm{TiO}_{2} / \mathrm{MgO}$ ratio ranges from 0.3 to 0.65 , corresponding to the average shale composition (PAAS), but is relatively lower than UCC. By contrast, $\mathrm{PL}$ is characterized by strong variability in $\mathrm{MgO}$ values and a poor $\mathrm{MgO} / \mathrm{TiO}_{2}$ correlation indicating that both elements are hosted by different minerals. PL values stay within the Alpine molasses compositional range (Fig. 4). Finally, Saharan dust samples are slightly richer in $\mathrm{MgO}$.

Some elements are good markers of sediment provenance. In this study, loess, palaeosols and potential sources are compared through two ternary plots $(\mathrm{CaO}-\mathrm{Zr}-\mathrm{Rb}$ and $\mathrm{CaO}-\mathrm{Nb}-\mathrm{Zr}$, respectively; Fig. 5). $\mathrm{Rb}$, which is less mobile than $\mathrm{K}$, is hosted by $\mathrm{K}$-feldspars, micas and clay minerals (Heier and Billings, 1970; Nesbitt et al., 1980) and represents the potassic pole, whereas carbonate sources gather near the $\mathrm{CaO}$ pole. High $\mathrm{Zr}$ content is a good indicator for loess deposits (Scheib and Lee, 2010; Scheib et al., 2014; Taylor et al., 1983) and for sediments enriched in resistant minerals. $\mathrm{Nb}$ is a poorly mobile element found in a variety of common minerals (e.g., Ti oxides, biotite, titanite, zircon) and is abundant in residual soils thanks to its resistance to chemical weathering (Scheib et al., 2012). In the $\mathrm{CaO}-\mathrm{Zr}$ $\mathrm{Rb}$ diagram, most samples are lined up subparallel to the $\mathrm{CaO}-\mathrm{Zr}$ axis, strongly suggesting a genetic relationship between loess ( $R L+P L)$ and Alpine alluvium (Fig. 5a). Carbonates are mostly concentrated within the coarser fraction of loess and within Alpine alluvium while $\mathrm{Zr}$ is hosted by the 
finer fraction of loess and, to a lesser extent, within FMC alluvium. Owing to weathering, decalcified loess ("Dombes loess") plot close to the $\mathrm{Zr}$ pole. The fine fraction of palaeosols $(<32$ and $<10 \mu \mathrm{m})$ show a greater $\mathrm{Rb}$ content relatively to loess fractions because of a greater amount of clay minerals. As shown by the proximity between the fine fraction of loess and the Saône alluvium on the $\mathrm{CaO}-\mathrm{Nb}$ $\mathrm{Zr}$ diagram, a contribution of the Saône basin to aeolian dust seems likely (Fig. 5b). High Nb contents (together with $\mathrm{Ti}$ and $\mathrm{Zr}$ ) are typical of Saharan dusts (Castillo et al., 2008), except for Morocco (Moreno et al., 2006), and reflect the deflation of weathered rocks. Nb shows that Saharan dusts have had little or no contributed to loess.

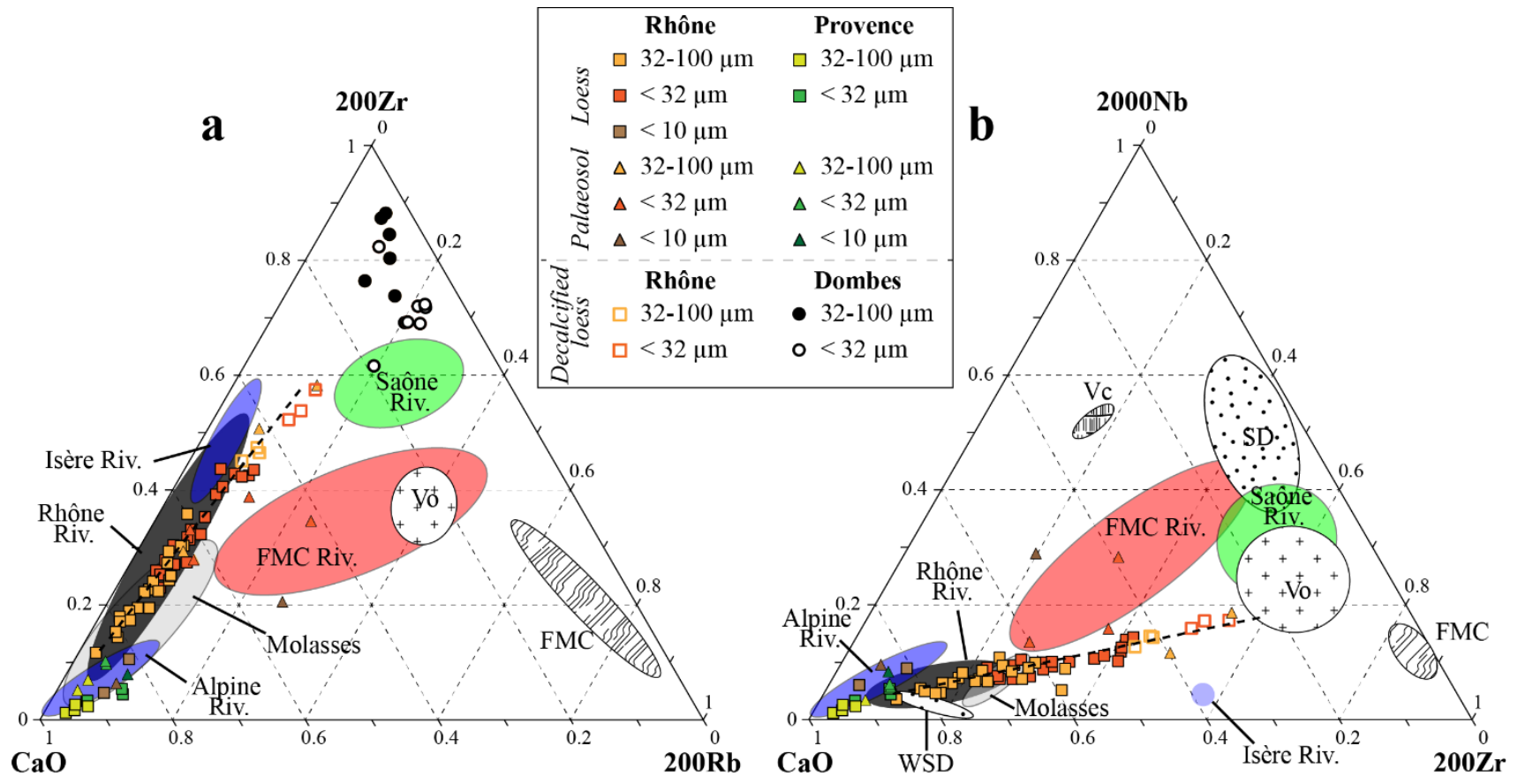

Fig. 5: $\mathrm{CaO}-\mathrm{Zr}-\mathrm{Rb}$ (a) and $\mathrm{CaO}-\mathrm{Nb}-\mathrm{Zr}$ (b) ternary plots for separate fractions of $\mathrm{PL}$ and $\mathrm{RL}(<10,<32$ and 32-100 $\mu \mathrm{m}$ ) and for potential alluvial sources from the Rhône-Saône catchment area in this study and FOREGS data from Salminen et al. (2005). Compositional field for potential source rocks are also shown: granite from the Vosges (Vo) (Altherr et al., 2000); gneiss from the French Massif Central (FMC) (Couzinié et al., 2017); volcanic rocks (Vc) from the FMC (Sasco et al., 2017); sandstones from the Alps (von Eynatten, 2003); Saharan dusts from Tarfaya (WSD, Morocco) and other locations (SD) (Castillo et al., 2008; Moreno et al., 2006).

\subsection{Loess REE compositions and potential sources}

Unlike other elements, REEs have low mobility in near-surface environments and are found in a broad suite of minerals. Furthermore, the REE content of sediments is representative of the lithological composition of sources and therefore, REEs provide key information on sediment provenance (McLennan, 1989). In this study, we applied the geochemical approaches successfully used by Sun et al. (2007) and Muhs and Budahn (2006). We used chondrite-normalized (McDonough and Sun, 1995) (represented by the letter " $N$ ") plot of $\mathrm{La}_{\mathrm{N}} / \mathrm{Yb}_{\mathrm{N}} \mathrm{vs}$. $\mathrm{Eu} / \mathrm{Eu}^{*}$ where Eu anomaly is defined by $\mathrm{Eu} / \mathrm{Eu}^{*}=$ $\mathrm{Eu}_{\mathrm{N}} /\left(\mathrm{Sm}_{\mathrm{N}} \mathrm{x} \mathrm{Gd}_{\mathrm{N}}\right)^{0.5}$. High $\mathrm{Eu} / \mathrm{Eu}^{*}$ values reflect higher Eu concentration because of plagioclase abundance, and are typical of oceanic crust material (Taylor and McLennan, 1985). La $/ \mathrm{Yb}_{\mathrm{N}}$ ratio indicates Light Rare Earth Elements (LREE) enrichment. 


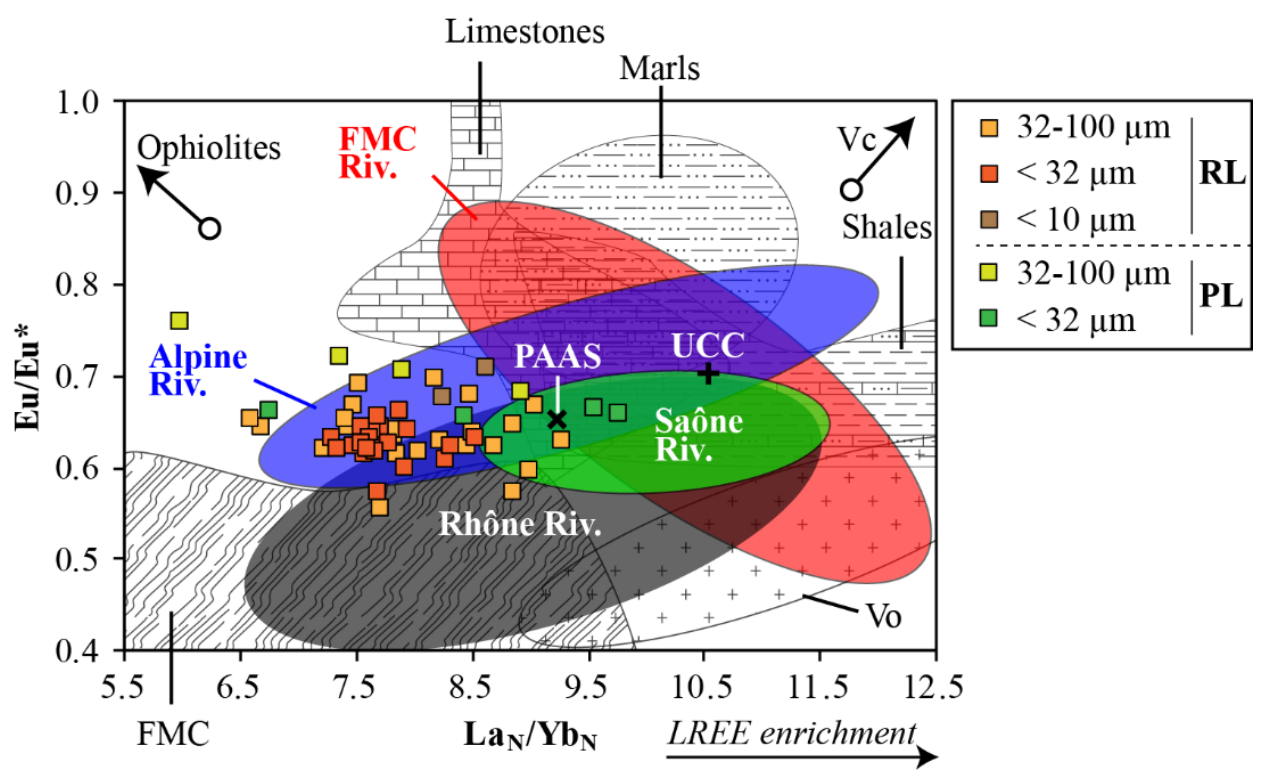

Fig. 6: Plot of $\mathrm{La}_{\mathrm{N}} / \mathrm{Yb}_{\mathrm{N}}$ vs. $\mathrm{Eu} / \mathrm{Eu}^{*}$ for coarse $(32-100 \mu \mathrm{m})$, fine $(<32 \mu \mathrm{m})$ and ultrafine $(<10 \mu \mathrm{m})$ fractions of loess compared to the compositional range of alluvial deposits from Alpine Rivers (Drome, Durance, Aigues, Isère, Ouvèze), French Massif Central Rivers (Ardèche, Cèze, Doux, Gard, Eyrieux), Rhône River and Saône River alluvial deposits from this study and FOREGS data from Salminen et al. (2005). The UCC and PAAS values are from Rudnick and Gao (2003) and Condie (1993). respectively. Bedrock data: Vosges (Vo) granitic rocks are from Altherr et al. (2000), FMC gneiss from (Couzinié et al. (2017) and Steinmann and Stille (2008), limestones and marls from Bellanca et al. (1997), shales from Rantitsch et al. (2003), ophiolites from Manatschal et al. (2011) and FMC volcanic rocks (Vc) from Sasco et al. (2017).

All rivers in the Rhône catchment area have significant or slightly negative Eu anomaly (Fig. 6). Samples from the Rhône River show greater Eu depletion than the samples from the other rivers investigated, and $\mathrm{Eu} / \mathrm{Eu}^{*}$ values are ranging from 0.32 to 0.69 . The Ardèche and Gard Rivers in the FMC have the highest $\mathrm{Eu} / \mathrm{Eu}^{*}$ values (0.88 and 0.82 respectively), reflecting the contribution of basaltic rocks. The Saône River as well as FMC Rivers show the greatest LREE enrichment, which is related to the presence of granites in their respective catchment areas. RL and PL plot in between sedimentary rocks (limestones, marls, shales) and granites and gneiss. Loess samples are slightly depleted in LREE compared to UCC and PAAS. In the plot, the fine fraction $(<32 \mu \mathrm{m})$ of RL shows strong homogeneity with respect to LREE whereas the coarse fraction $(32-100 \mu \mathrm{m})$ is more scattered. The geochemical signature of Alpine Rivers (Aigues, Drôme, Durance, Isère, Ouvèze) encompasses almost all loess samples. The high $\mathrm{Eu} / \mathrm{Eu}^{*}$ values of PL samples suggest that their sources include mafic or ultramafic rocks (e.g., ophiolite complex).

\subsection{Geochemistry of European loess}

The biplot derived from the multivariate analysis of loess samples alone explains $59.52 \%$ of the total variance (Fig. 7). The observed poles are as follow: (i) the pole of Ca-rich minerals (calcite, dolomite, anorthite) also bearing $\mathrm{Mg}$ and $\mathrm{Sr}$; (ii) the pole of resistant minerals (e.g., quartz, zircon, Ti oxides) including immobile elements such as $\mathrm{Ti}, \mathrm{Nb}, \mathrm{Zr}, \mathrm{Y}, \mathrm{Al}, \mathrm{Si}$; (iii) the pole of $\mathrm{Fe}$ oxides with other siderophile elements ( $\mathrm{Cu}, \mathrm{Ni}, \mathrm{V}, \mathrm{Zn}$ ); (iv) the group including Na-bearing minerals (albite), and (v) Kbearing minerals (K-felsdpars, phyllosilicates) represented by $\mathrm{K}, \mathrm{Rb}$ and $\mathrm{Ba}$. The UCC average chemical composition plots near the barycentre of the biplot. 


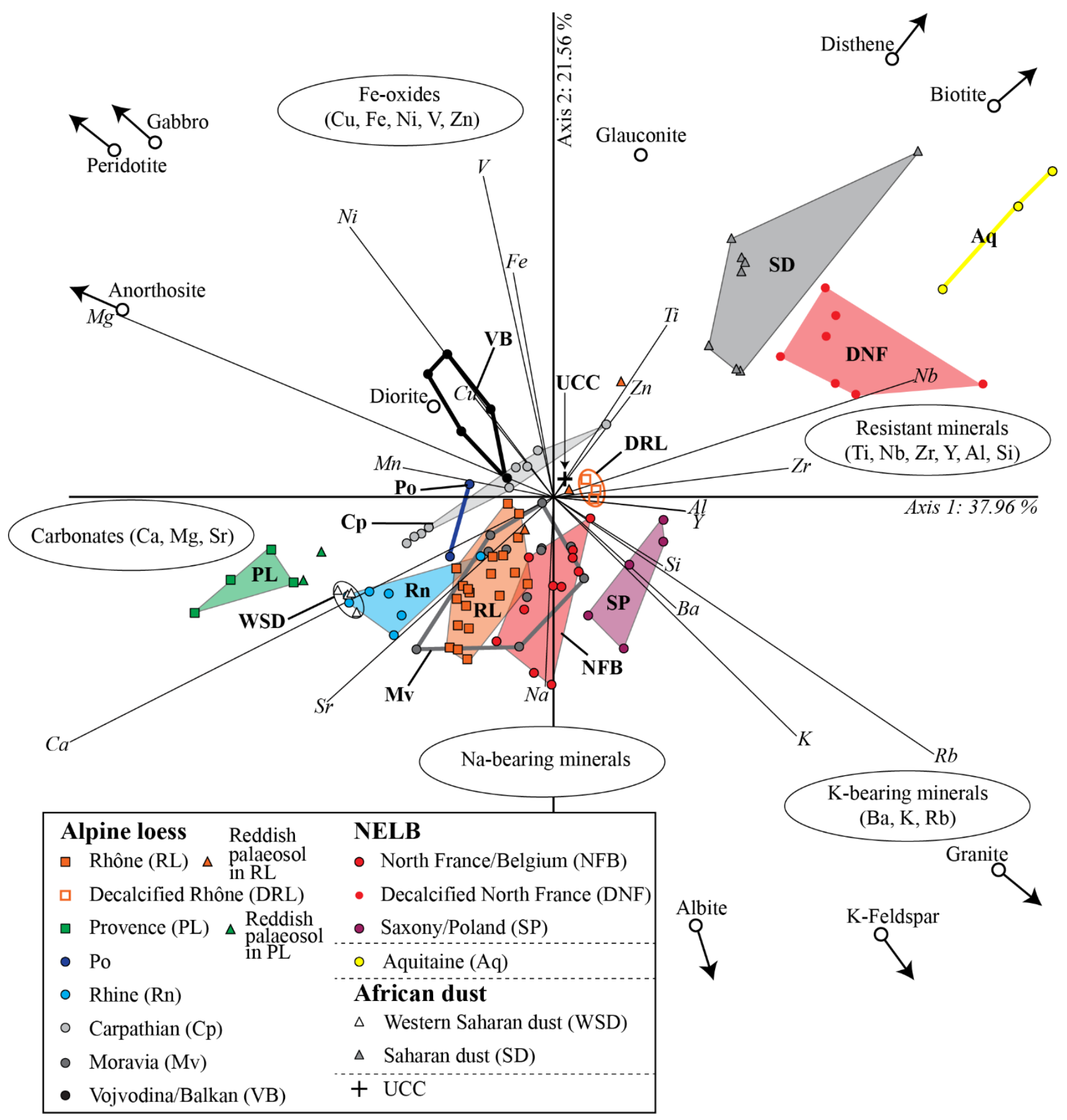

Fig. 7: Compositional biplot of major and trace elements of European loess samples (fraction $<100$ $\mu \mathrm{m})$. Data sources: Aquitaine loess (this study), Vojvodina/Balkan regions (Obreht et al., 2016, 2015), Carpathian basin (Újvári et al., 2014, 2008), southern Moravia region (Adamová et al., 2002), Susak island in the Po Valley (Mikulčić Pavlaković et al., 2011), Rhine basin (this study; Taylor et al., 1983), North France/Belgium plateau (this study; Chauvel et al., 2014; Gallet et al., 1998), Saxony/Poland (this study) and African dust (Castillo et al., 2008; Moreno et al., 2006). Additional geochemical references (diorite DR-N, anorthosite AN-G, granite GH, microgabbro PM-S, albite AL-I, glauconite GL-O, K-feldspar FK-N, Disthene DT-N, Biotite Mica-Fe) are taken from CRPG-SARM (Nancy) published by Carignan et al. (2001) and Govindaraju (1995), while the average of 39 peridotite xenoliths samples from the French Massif Central is from Zangana et al. (1999). The UCC values are from (Rudnick and Gao, 2003). 
The horizontal axis (Axis 1; Fig. 7) is mainly determined by the carbonate content and accounts for $37.96 \%$ of the total variance. This axis opposes Ca-rich European loess to African dust (except for samples from western Morocco) and to decalcified loess from Aquitaine and northern France, which are close to the pole of resistant minerals (Fig. 7). Low Ca contents may be inherited from rocks outcropping in river catchment areas or may reflect syn- or post-sedimentary decalcification, or intense sediment recycling. Within calcareous loess, regional groups can be individualized. Loess located in the Alpine forelands (Provence, Rhône, Rhine, Po, Carpathian, Moravia) are richer in CaO than loess deposited near the Fenno-Scandinavian Ice Sheet (FIS) (Saxony/Poland). The latter plot closer to Kbearing minerals and the pole of resistant minerals, which reflects felsic Scandinavian shield sources. In contrast, the high $\mathrm{Ni}, \mathrm{Cu}$ and $\mathrm{Fe}$ values found in Vojvodina/Balkans loess strongly suggest a contribution from sources with a mafic composition. For the Moravia, northern France and Belgium loess, the distinction is not as clear. They display an intermediate composition between peri-alpine loess and FIS-derived loess. Finally, the calcareous loess of the Rhône Valley are relatively homogeneous and their compositional field overlaps those of the Rhine and Moravia loess.

\section{Discussion}

\section{1._Rhône loess: weathering and provenance}

\subsubsection{Weathering}

Several elemental ratios are used to estimate the weathering intensity of loess. The CPA is particularly adapted to poorly weathered sediments (Buggle et al., 2011) since weathering first impacts plagioclases rather than K-feldspars (Nesbitt and Young, 1989). The mean CPA value for samples from RL is 86.8 (Fig. A3). This value is low compared to PAAS, i.e., 94 (Condie, 1993), but slightly higher than the UCC value, which is $\sim 82.5$ (Rudnick and Gao, 2003) (Fig. A3). PL have much higher CPA values, between 90.3 and 93.1, reflecting either more intense syn- or post-depositional chemical weathering of loess or intense weathering of sources (Fedo et al., 1995). Since the loess are rich in carbonates and do not display obvious dissolution features, the last hypothesis appears the most likely. The lithology of catchments in Provence, and especially of the Durance basin, includes abundant finegrained and mature sedimentary rocks (shales, marls) that account for the high CPA values.

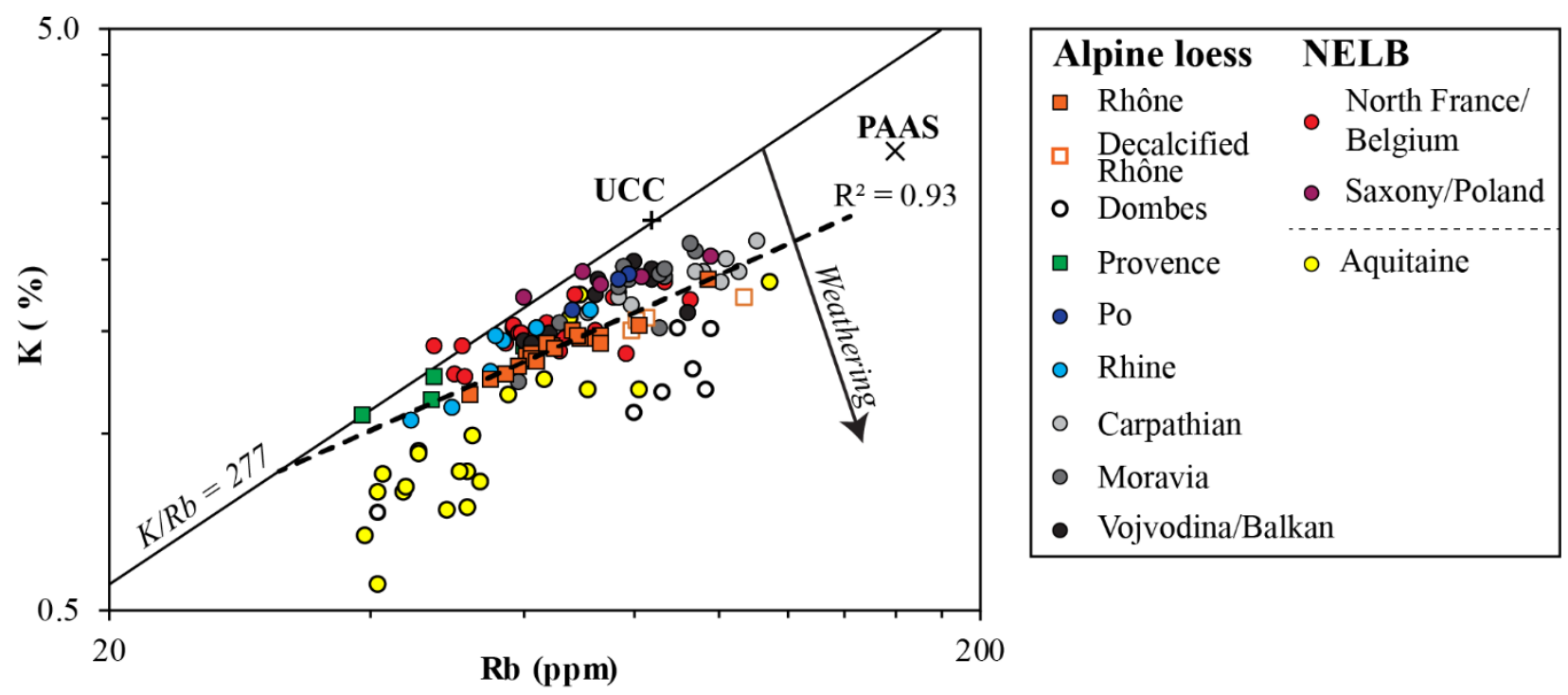

Fig. 8: $\log K$ vs. $\log R b$ plot for European loess deposits. The " $K / \mathrm{Rb}=277$ " line represents the average UCC ratio. Weathering trends were calculated from data of the Toorong weathering profile (Nesbitt et al., 1980). Same data sources as in Fig. 7 with additional data for Aquitaine loess (Sitzia et al., 2017), Carpathian loess (Profe et al., 2018; Schatz et al., 2015), North France loess (Smykatz-Kloss, 2003). 
Beside the $\mathrm{CPA}$, the $\mathrm{K} / \mathrm{Rb}$ ratio is used to estimate the weathering intensity of $\mathrm{K}$-bearing minerals (Nesbitt et al., 1980; Wronkiewicz and Condie, 1990), since $\mathrm{K}$ is more mobile than Rb thanks to its smaller ionic radius. In the log-K vs. log- $\mathrm{Rb}$ diagram, $\mathrm{RL}$ and $\mathrm{PL}$ display a constant $\mathrm{K} / \mathrm{Rb}$ ratio $\left(\mathrm{R}^{2}=\right.$ 0.93 for RL) with $\mathrm{K}$ and Rb concentrations slightly lower than mean UCC composition (Fig. 8). This result is typical of the first weathering stages described by Nesbitt et al. (1980). Only the Aquitaine loess, Dombes loess and decalcified loess from the Lyon area are significantly depleted in K, indicating an almost complete weathering of Al-silicates, particularly biotite into vermiculite Nesbitt et al. (1980).

As a whole, RL and PL underwent low to moderate weathering. In the context of the Last Glacial, this resulted from a combination of low precipitation and prevailing physical erosion processes (Újvári et al., 2014). It implies a limited modification of the chemical composition and allows a direct comparison with potential sources.

\subsubsection{Rhône loess: an alpine influence}

The results on REEs and major and trace elements highlight a genetic relationship between loess and Ca-rich sediments from rivers draining the AIS (e.g., Durance, Drôme, Isère and Rhône). The relative richness in $\mathrm{Si}$, Hf and $\mathrm{Zr}$ of RL witnesses mineralogical sorting, especially of quartz and zircon. Zircon excess is often documented in European loess (Chauvel et al., 2014; Scheib et al., 2014; Taylor et al., 1983). It is assumed to result from the removal of poorly resistant minerals by glacial abrasion and subsequent transport in fluvial and aeolian contexts (Buggle et al., 2008; Profe et al., 2016). Aeolian transport and sorting obviously play a major role, as shown by a relatively lower $\mathrm{Ti} / \mathrm{Zr}$ ratio which reflect a systematic $\mathrm{Zr}$ enrichment of the loess compared to alluvium in the same catchment area (Fig. 9). Miocene molasses, whose geochemical composition is close to that of loess except for higher content in $\mathrm{MgO}$ (Figs. 4 and 5), may have acted as secondary dust sources. Since the deflation-related landforms in molasses (desert pavements, pans and yardangs) are located in the lower Rhône Valley (Bosq et al., 2018), their contribution was likely only local.

Loess homogeneity, stronger than that of alluvium, is interpreted as the result of dust mixing in the atmosphere (Gallet et al., 1998) and grain-size sorting (Fig. 2). The separate analysis of two fractions $(<32 \mu \mathrm{m}$ and 32-100 $\mu \mathrm{m}$ ) shows that their composition is relatively similar and suggests that the two main modes come from a single alluvial source. This resulted from the simultaneous capture by the riparian vegetation of sandy and silty particles in saltation and suspension from the riverbed (Bosq et al., 2018) as documented in some modern environments (Bullard and Austin, 2011; Lin et al., 2016). The distribution, geometry, grain-size gradients and geochemical composition all point to the Rhône River as the main contributing source. Ternary diagrams (Fig. 5) suggest, however, that finer inputs from the remote Saône basin further north may also have contributed to the Rhône loess. 

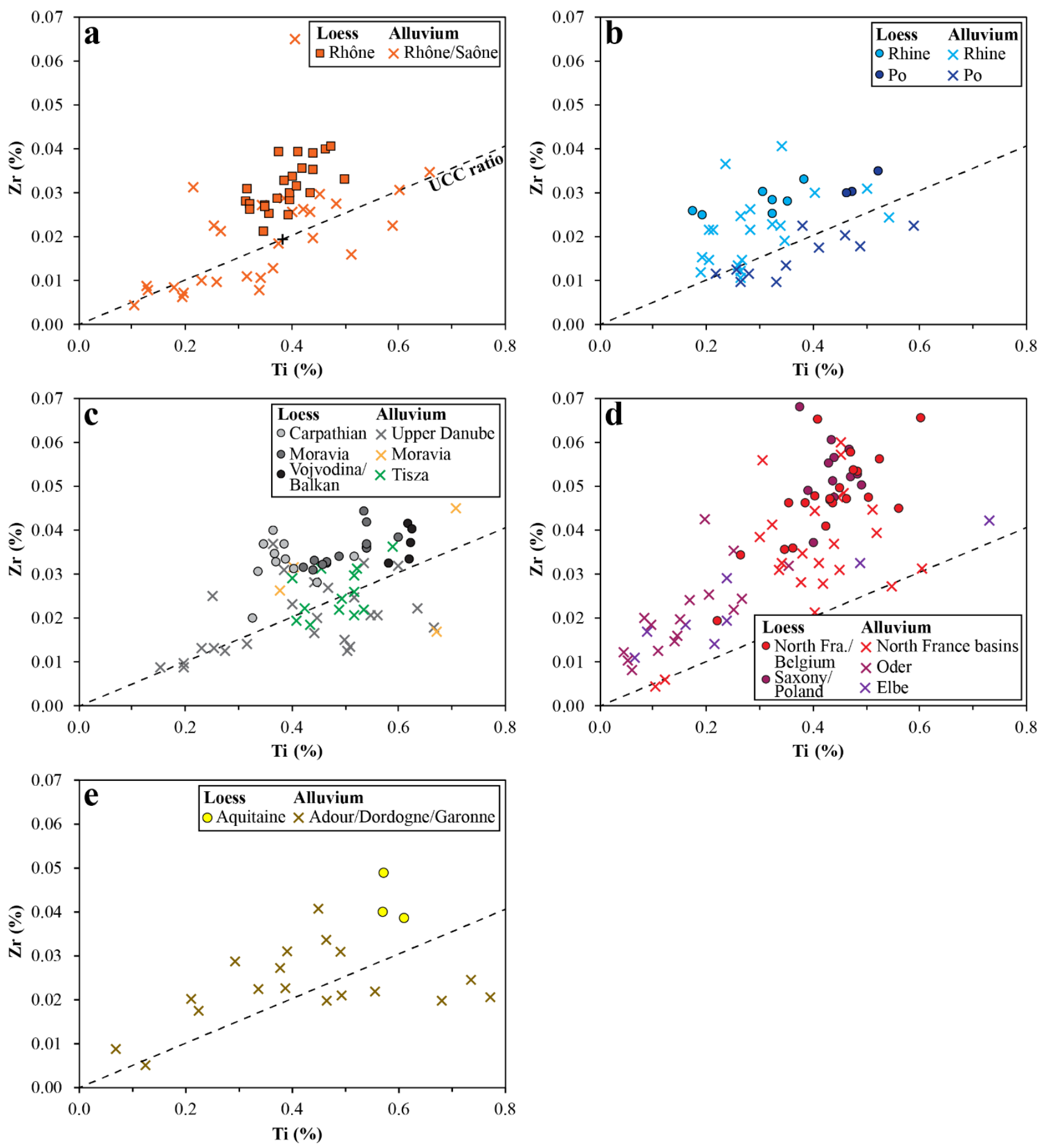

Fig. 9: Ti and Zr plot of European loess deposits from several regions (Rhône/Saône (a), Rhine/Po (b), Danube (c), North European plains (d) and Aquitaine (e)) and the compositional range of alluvial deposits from their respective catchments areas (FOREGS database, Salminen et al. (2005). Same data sources as in Figs. 7 and $\mathbf{8}$ with additional data for Poland loess (Waroszewski et al., 2018).

\subsubsection{Loess of Provence sources}

Despite the low amount of studied samples $(n=8)$, the geochemical composition of PL does not overlap that of $\mathrm{RL}$ and shows (i) $\mathrm{CaO}$ enrichment, (ii) higher $\mathrm{MgO}$ content, and (iii) higher $\mathrm{Eu} / \mathrm{Eu}^{*}$ ratio (from 0.66 to 0.76 ) (Fig. 6). High $\mathrm{MgO}$ values result from abundant dolomite ( $>5 \%$ ) and implies that (i) physical erosion prevailed over chemical weathering (Újvári et al., 2014), and (ii) transport was 
short since this mineral has poor resistance to abrasion (Römer et al., 2016). The relatively high Eu anomaly most likely indicates a contribution of ultramafic rocks (ophiolite complex), even though limestones can have close values (Fig. 6). Source tracing shows that dust came mainly from the alluvium of the Durance River. The PL can therefore be seen as an autonomous aeolian system located in the Durance catchment (Fig. 3). Surrounding reliefs probably acted as a topographical barrier and limited external dust inputs.

The sandy loess of Cuges-les-Pins, rich in dolomite (21\%) (Fig. 3), which accumulated over a significant thickness $(6-8 \mathrm{~m})$ on the windward side of a closed depression, form another isolated aeolian system. Their coarse grain-size implies reduced transport in saltation or short-term suspension. The distribution of these sandy loess and their geochemical composition suggest that most of the sedimentary material may have come from alluvial fans derived from the dolomitic outcrops dominating the karstic depression or from lacustrine deposits that filled in the depression during humid episodes (Sivan et al., 2018).

\subsubsection{Saharan dust in the Rhône Valley?}

Geochemical analyses show that Sahel and Saharan dust are rich in immobile elements (Zr, Hf, Th, $\mathrm{Nb}, \mathrm{Ti}$ ) and are depleted in soluble elements (Na, K, Rb) (Bristow et al., 2010; Castillo et al., 2008; Moreno et al., 2006; Scheuvens et al., 2013). In addition, they exhibit moderate iron oxides concentration. Multivariate analysis does not suggest any relationship with RL and PL (Fig. 7), whereas dust coming from the coastal sedimentary basins (Western Sahara, Morocco) has a geochemical composition closer to that of RL and PL. However, Moroccan dust is richer in $\mathrm{Rb}$ and $\mathrm{Nb}$ (Fig. 5) and depleted in HREE. Reconstitutions of dust flux trajectories from Morocco through satellite images or through clay minerals (palygorskite) suggest significant fallouts in southern France (BoutRoumazeilles et al., 2007; Varga et al., 2013). The finest particles $(\sim 10 \mu \mathrm{m})$ of the red palaeosols interstratified within loess in southeast France could be, therefore, the result of dust fallouts from Western Sahara. However, the fingerprint of such inputs was not detected in the studied samples. New geochemical and mineralogical data on palaeosols and the finest fraction of loess are required to better evaluate the potential Saharan contribution.

\subsection{Comparison with other European loess}

The multivariate analysis of loess samples highlights significant differences between European regions, particularly with regard to the amount of carbonate and resistant mineral materialized by factor 1 (F1) values (Fig. 7). Fig. 10 shows that the highest factor 1 (F1) values are located along the Atlantic coast and in northern Europe along the FIS margin, whereas negative values are characteristics of the peri-alpine domain, the Mediterranean regions and Central Europe. The distribution is non-random and several physico-chemical processes can account for it.

\subsubsection{Lithology of sediment sources}

The high carbonate content of the loess deposited near Alpine Rivers (Rhône, Danube, Rhine and Po) is related to the predominance of carbonate rocks $(\sim 32 \%)$ in the areas covered by the AIS during MIS 2 (Fig. 10). In contrast, the FIS extended over land composed of $31 \%$ felsic rocks, which mainly supplied K-containing minerals, quartz and zircon as observed in the loess of Poland and Saxony (Fig. 10). This suggests that the variability of the geochemical composition of European loess mostly reflects the lithology of the nearby glacierized areas. Many studies in cold environments show that current aeolian sedimentation is usually closely associated to fluvio-glacial systems (Arnalds et al., 2016; Bullard, 2013; Bullard and Mockford, 2018; Dijkmans and Törnqvist, 1991; Hugenholtz and Wolfe, 2010). These studies highlighted the role of glacial abrasion and, to a lesser extent, of mechanical 
weathering due to freeze-thaw processes in the production of silt-sized particles, which are then carried towards alluvial plains by meltwater (von Eynatten et al., 2012; Wright, 2001). Unconsolidated finegrained material is exposed on wide floodplains where it is subject to deflation (Smalley et al., 2009; Stevens et al., 2011; Wright, 2001). The coastal aeolian system of Aquitaine (SW France) is an exception. As shown by Sitzia et al. (2017), dust was provided mostly by the abrasion of coversands exposed to deflation on the emerged continental plateau.

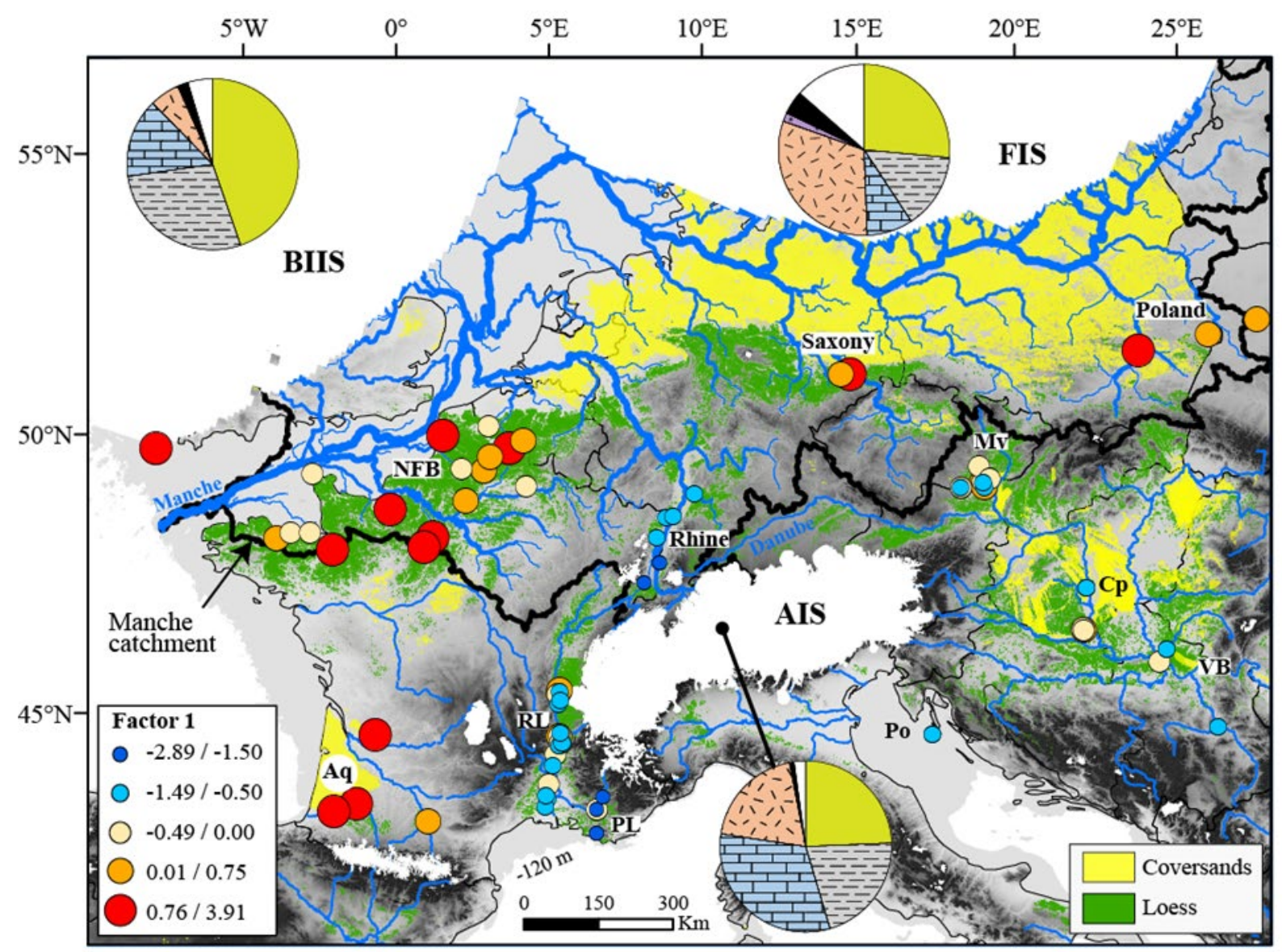

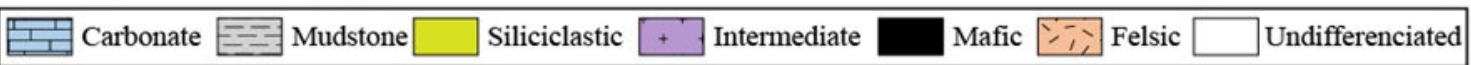

Fig. 10: Spatial distribution of F1 factor values of the European loess deposits (see Fig. 6). European aeolian deposits distribution from Bertran et al. (2016) with additional data from Bosq et al. (2018) and Lindner et al. (2017). Pie-charts refer to rock types covered by ice sheets. The geological data are as in Fig. 3. The palaeo-Fleuve Manche catchment during the LGM at $22.7 \mathrm{ka}$ as well as the associated river network is from Patton et al. (2017). British-Irish Ice Sheet (BIIS), Fenno-Scandinavian Ice Sheet (FIS), Alpine Ice Sheet (AIS) and other LGM glaciers are from Ehlers and Gibbard (2004) and Patton et al. (2017).

Each loess region in Europe exhibits varying Eu anomalies, ranging from 0.52 to 0.70, which are inherited from source rocks (Fig. A3). High Eu/Eu* values for two subgroups of the Rhône and Danube basins (the Provence and Vojvodina/Balkans loess respectively) indicate a contribution of mafic sources (Muhs, 2018). For the latter subgroup, the influence of the ultramafic rocks outcropping in the Zapadna Morava River catchment is also highlighted by high Ni and Cr values (Obreht et al., 2016).

Although sharing common geochemical and grain-size properties, the loess accumulated around the palaeo-Manche River (North France, Belgium) have substantial compositional differences with respect 
to the carbonate content and $\mathrm{Eu} / \mathrm{Eu}^{*}$ ratio values. Some authors already underlined such variability through mineralogical studies (Balescu, 1988; Juvigné, 1985, 1978; Lautridou et al., 1984; Lebret and Lautridou, 1991; Pirson et al., 2018). The main factor involved is a mixing between (i) dust rich in Kbearing minerals yielded by Scandinavian felsic rocks and (ii) more limited, carbonate-rich inputs from the Mesozoic sedimentary basins (Paris basin, North German basin). The latter are also rich in resistant minerals (Zr, Ti) (Fig. 9d) coming from the weathering products that mantle part of the Paris basin and the Cenozoic alluvial deposits derived from Hercynian ranges (FMC, Rhenish Shield). These particles probably underwent long fluvial transport before wind reworking. As a result, the composition of NELB samples varies according to the FIS proximity and the relative importance of more regional inputs.

\subsubsection{Weathering intensity}

Lautridou et al. (1984) noticed that the carbonate content of Last Glacial loess gradually increases from West to East in France and ranges from $<12 \%$ to 20\%. Besides, Frechen et al. (2003) showed that mass accumulation rates (MARs) during MIS 2 increased in Europe according to a NW-SE gradient. For these authors, such gradients would be climate-induced and would reflect a moisture gradient between the Atlantic coast and the drier inner continent. However, the values of factor F1 and the CPA do not highlight any clear difference between eastern and western loess but show a random distribution of values along the NELB (Figs. 10 and A3). In Europe, the CPA ranges between 86 and 93, except for Aquitaine loess and, to a lesser extent, English loess that have CPA values over 93 (Fig. A3). Therefore, chemical weathering and sedimentation rates cannot explain the variability in soluble elements $(\mathrm{Na}, \mathrm{Ca})$ found in loess at the continental scale.

The chemical variability of source material in each catchment, and especially the relative amount of sediments derived from felsic and mafic rocks, potentially controlled the CPA (Buggle et al., 2011). To test this hypothesis, the CPA was compared to the $\mathrm{Sc} / \mathrm{Th}$ ratio, which are two immobile elements often used as indicators to distinguish felsic from mafic sources (Guo et al., 2018; Taylor and McLennan, 1985). The lack of correlation between CPA and Sc/Th (Fig. 11) clearly indicates that the nature of the sources have no impact on the CPA.

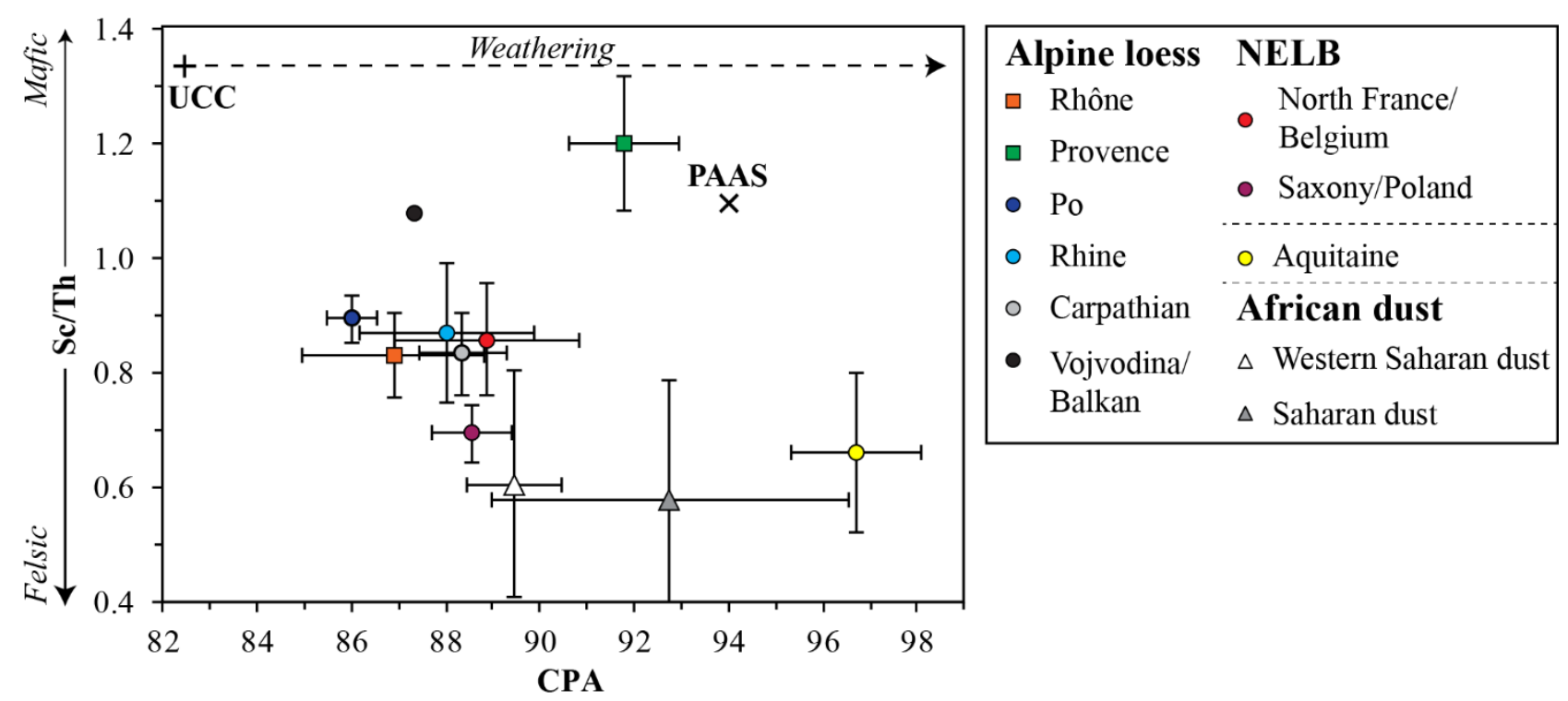

Fig. 11: Plot of CPA vs. Sc/Th ratio in loess deposits. Data are as in Fig. 7. 
During fluvial transport, sorting occurs according to particle size, density and shape leading to significant modifications in sediment mineralogy and geochemistry (Garzanti et al., 2011, 2010). Aeolian transport most likely produces similar modifications. The $\mathrm{Al}_{2} \mathrm{O}_{3} / \mathrm{SiO}_{2}$ ratio is sensitive to grain-size sorting since Si-rich tectosilicates (quartz, feldspars) are over-represented in the coarser fraction, whereas Al-rich phyllosilicates constitute a significant part of the finer fraction (Bouchez et al., 2012; Guo et al., 2018; Liang et al., 2013). To study the impact of grain-size sorting on CPA, this proxy was compared to the $\mathrm{Al}_{2} \mathrm{O}_{3} / \mathrm{SiO}_{2}$ ratio. A positive correlation exists between CPA and $\mathrm{Al}_{2} \mathrm{O}_{3} / \mathrm{SiO}_{2}$ for samples from the same loess region (Fig. 12). Na, mostly hosted by plagioclases (albite), is more abundant (low CPA) in the coarser fraction (low $\mathrm{Al}_{2} \mathrm{O}_{3} / \mathrm{SiO}_{2}$ ) whereas it is significantly depleted (high CPA) in the finer fraction. As a result, the CPA variability does not only reflect chemical weathering specific to each region but also grain-size and mineralogical sorting during fluvial and aeolian transport. As shown in Fig. 8, the amount of K-containing minerals does not vary much in the studied loess, which testifies to the inefficiency of chemical weathering in Europe during the Last Glacial.

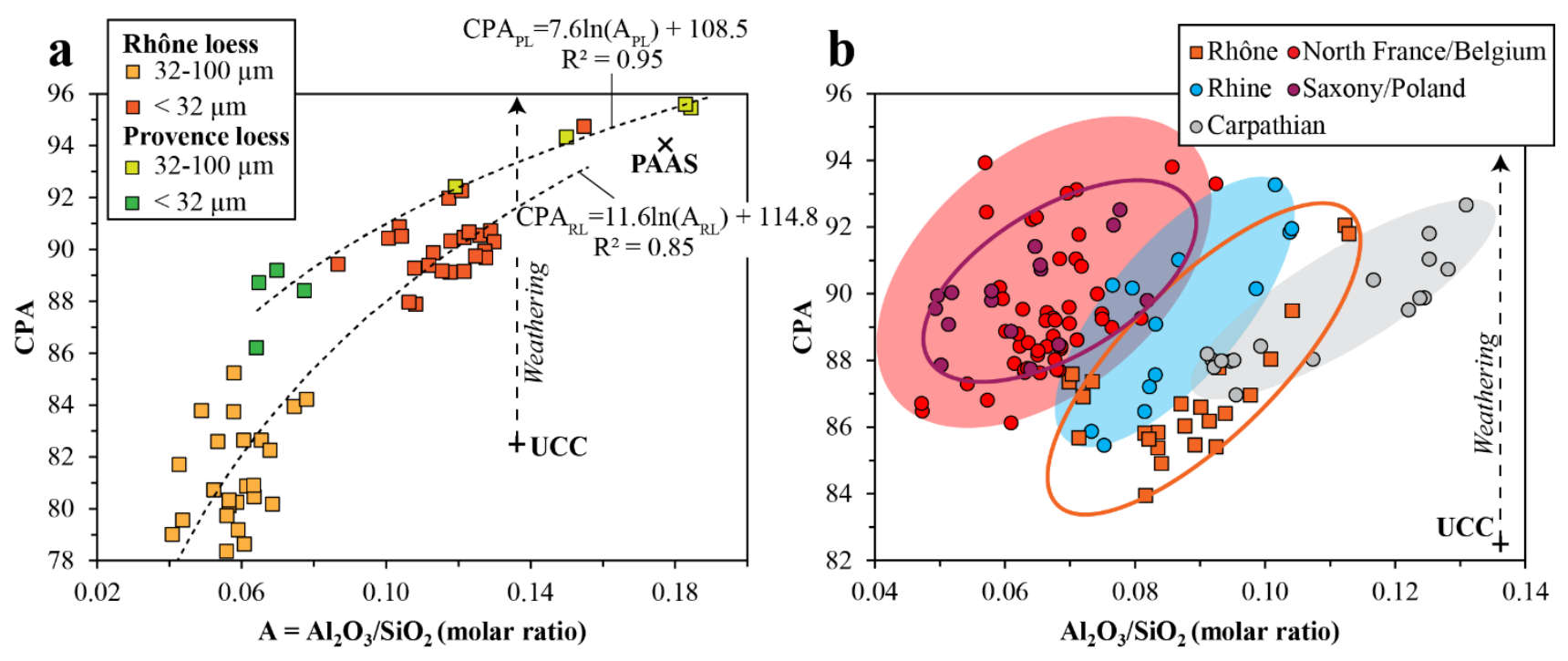

Fig. 12: Correlation between $\mathrm{CPA}$ and $\mathrm{Al}_{2} \mathrm{O}_{3} / \mathrm{SiO}_{2}$ ratio in the loess samples from the study area (a) and Europe (b). Data sources: Carpathian loess (Bösken et al., 2017; Profe et al., 2018; Schatz et al., 2015; Újvári et al., 2014, 2008), North France/Belgium loess (this study, Chauvel et al., 2014; Gallet et al., 1998; Jamagne, 1973; Lautridou, 1985; Lautridou et al., 1984; Smykatz-Kloss, 2003), Rhine loess (this study, Kühn et al., 2013; Schatz et al., 2015; Taylor et al., 1983), Saxony/Poland loess (this study, Raczyk et al., 2015; Skurzyński et al., 2019, 2017; Waroszewski et al., 2018).

During this period, the main rivers drained wide areas (especially the palaeo-Manche and Danube Rivers) extending from the high mountain ranges covered by glaciers to the lower plains. River sediments underwent repeated storage and remobilization phases in alluvial plains (Bouchez et al., 2012). As a result, the transfer time of sediments from source to sink was quite long, from several thousands to several hundred thousands of years (Granet et al., 2010, 2007). At such time scale, climate-warming periods during the Pleistocene probably had a major impact on chemical weathering. Despite this, weathering of alluvium-derived dust remained low to moderate and homogeneous at the scale of each catchment, strongly suggesting that the lithology of sources was the main controlling factor. Therefore, the differences in the geochemical composition of loess are mainly related to the lithological and textural properties of source rocks, while the variability of the weathering proxies is largely controlled by grain-size sorting during transport. Low to moderate chemical weathering played 
a role in the slight decrease of $\mathrm{K}$-bearing minerals in loess whereas the $\mathrm{CaO}$ content was dependent on factors such as: (i) the amount of carbonates in the sources (source effect), which is assumed to be dominant in the study area; (ii) syn-sedimentary climate-related weathering in some regions, which was responsible for the depletion of alkaline and alkali-earth elements $(\mathrm{Ca}, \mathrm{Mg}, \mathrm{Na}$ and $\mathrm{K}$ ) as well as for the enrichment in stable elements (Al, Ti) (Nesbitt et al., 1996, 1980; Nesbitt and Young, 1989); such weathering was favored in areas with low sedimentation rates (e.g., on the southern margin of the NELB in France); (iii) post-depositional chemical weathering of sediments older than the Last Glacial (e.g., Dombes loess) during one (or several) interglacial(s).

\subsubsection{Sediment recycling}

On the $\mathrm{Na}_{2} \mathrm{O} / \mathrm{Al}_{2} \mathrm{O}_{3}$ vs. $\mathrm{K}_{2} \mathrm{O} / \mathrm{Al}_{2} \mathrm{O}_{3}$ diagram proposed by Garrels and Mackenzie (1971), all European loess samples have $\mathrm{Na}_{2} \mathrm{O}$ concentrations significantly lower than igneous rocks (and UCC) and plot in the field of sedimentary rocks (Fig. 13). $\mathrm{Na}_{2} \mathrm{O}$ and $\mathrm{K}_{2} \mathrm{O}$ do not vary much within each loess region (North France/Belgium, Provence, Rhône, Rhine, Saxony/Poland, England, Po, Balkans, Carpathians and Moravia) but show large scatter from one region to another. Loess form a swarm around the shale trend line witnessing plagioclase depletion and progressive K-feldspars and illite enrichment (Fig. 13). $\mathrm{Na}$ loss (together with $\mathrm{Ca}$ ) is moderate for loess whereas $\mathrm{K}$ remains almost constant. These observations are in agreement with Gallet et al. (1998). Ca-rich peri-alpine loess, and especially loess from the Rhône basin, have the smallest maturity. On the contrary, Aquitaine loess, Saharan dust and to a lesser extent, English loess, show major Na depletion (higher CPA) and $\mathrm{K}$ decrease, testifying to higher weathering rates (Fig. 13). Such specificities are mainly the result of the various origin of dust. Aquitaine loess dusts came from sand abrasion upon aeolian transport and only marginally from alluvial sources (Sitzia et al., 2017). Repeated mobilization of the same sand source by the wind during the Pleistocene was responsible for a progressive enrichment in resistant minerals $(\mathrm{Zr}, \mathrm{Ti}, \mathrm{Nb})(\mathbf{F i g}$. 9e). For English loess, $\mathrm{Na}$ and $\mathrm{K}$ anomalies do not result from recycling but most likely reflect phyllosilicate-rich sources (mudstones) that underwent glacial abrasion under the BIIS (Fig. 10).

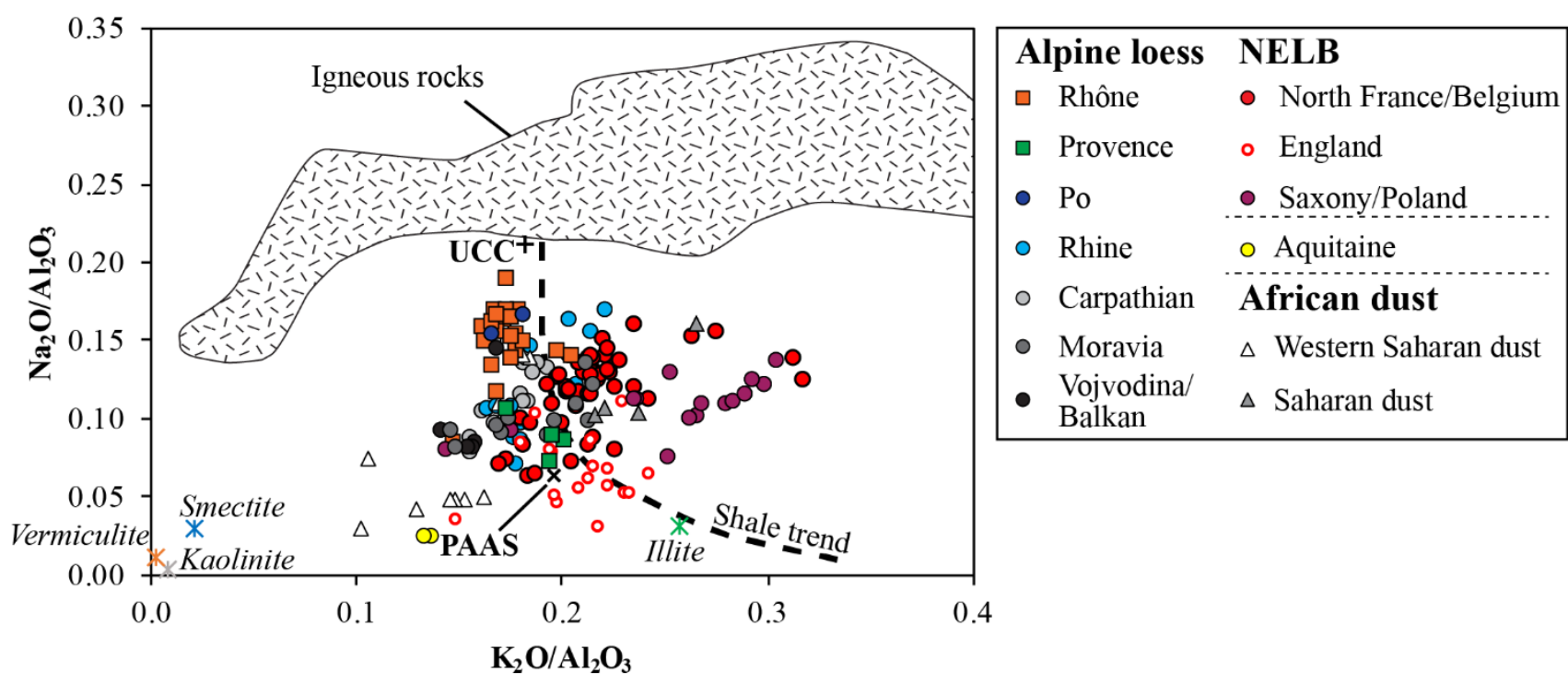

Fig. 13: Plot of $\mathrm{Na}_{2} \mathrm{O} / \mathrm{Al}_{2} \mathrm{O}_{3}$ vs. $\mathrm{K}_{2} \mathrm{O} / \mathrm{Al}_{2} \mathrm{O}_{3}$ ratios (Garrels and Mackenzie, 1971) comparing the European loess samples to igneous rocks and the shale compositional trend line. Data sources are as in Fig. 12, except for England loess (Parks and Rendell, 1992). The average composition of clay minerals is from Wilson (2013). 
Fluvio-aeolian recycling of silt-rich older sediments is considered by Frechen et al. (2003) as the main factor behind the extremely high loess sedimentation rates during MIS 2. In LGM fluvial systems, where riverbeds tend to widen rather than incise, lateral channel migration led to remobilization of former floodplain deposits and loess accreted alongside river banks. Such recycling is thought to have increased the amount of sediments available to deflation during successive glacial periods. Wind erosion surveys on Nebraskan loess (USA) also indicates that significant dust entrainment can occur in spite of its cohesion (Sweeney and Mason, 2013). In Europe, the LGM environments (low vegetation density, windy and dry climate) probably favored loess erosion. Recycling remains hard to estimate in this study, however, but is assumed not to have been a key factor. To better evaluate this factor, it would be necessary to examine in details the geochemical evolution of loess in the same area over several glacials.

\section{Conclusions}

The geochemical approach developed throughout this study, based on the comparison between loess and their potential sources with respect to major, trace and rare earth elements, allows to clearly identify the sources and to better constrain the respective role of weathering. The main conclusions that can be drawn are as follow:

(1) Rhône loess have a relatively homogenous geochemical composition, suggesting similar sources. A genetic relationship is obvious between loess and Ca-rich river sediments from the Alpine Ice Sheet (AIS). Provence loess have distinctive properties (higher CPA values, Eu anomaly, and $\mathrm{CaO}$ and $\mathrm{MgO}$ content) pointing to sources richer in dolomite and to a contribution of mafic rocks (Alpine ophiolite complex).

(2) As for other European loess, the weathering rate of loess is low in the Rhône basin. Variations in the weathering index are mostly related to the lithology of sources and to grain-size sorting during fluvial and aeolian particle transport. The lack of traceable weathering gradient in European loess highlights the minor role played by climate on the geochemical composition, at a time when mechanical erosion processes (glacial abrasion, freeze-thaw cycles) largely prevailed over chemical weathering.

(3) The influence of recycling of older aeolian sources remains hard to assess. Still, such process is probably at the origin of the high loess enrichment in resistant minerals and quartz in some regions. This is especially the case for the loess resulting from coversand abrasion (Aquitaine).

(4) Neither weathering nor sediment recycling are able to mask the geochemical signature of loess sources. Their composition is variable according to the region, reflecting the lithology of their respective catchment and particularly that of the areas affected by glacial abrasion. Greater loess homogeneity than alluvial sources resulted from particle mixing during transport in the atmosphere.

(5) At the European scale, the RL and PL plot well within the peri-alpine loess group supplied by the carbonate-rich rivers draining the AIS (Rhône, Danube, Rhine, and Po). On the other hand, the NELB was mainly supplied by dust rich in K-bearing minerals coming from Scandinavian felsic rocks. Additional regional contributions of $\mathrm{Ca}$-rich dust from the main sedimentary basins (Paris basin, North German basin) is also obvious in the western part of the NELB. Locally, contributions may have come from smaller glaciers (e.g., Carpathians).

The use of only trace elements or few isotopic markers would have not allowed to provide such conclusive results. This study highlights the heterogeneity of European loess, as sensed in previous studies (Gallet et al., 1998; Rousseau et al., 2014). As such, loess can hardly provide a good estimate of UCC elemental composition. It also shows that the mapping approach developed by Scheib et al. (2014) who used the distribution of $\mathrm{Zr}$ and $\mathrm{Hf}$ in soils, failed to identify many loess accumulation areas 
since strong $\mathrm{Zr}$ and $\mathrm{Hf}$ enrichment compared to average soil is mostly limited to NELB loess derived from the felsic Scandinavian sources.

\section{Acknowledgements}

This research was conducted in the PACEA laboratory with the financial support of the LaScArBx (research program of the Agence Nationale de la Recherche ANR-10-LABX-52), involving the University of Bordeaux and the University of Bordeaux-Montaigne. Additional support was also provided by the Institut National de Recherches Archéologiques Préventives (Inrap). We thank all the colleagues who sent samples for geochemical analysis, i.e. P. Antoine, L. Deschodt, E. Morin, O. Franc, P. Wuscher, Q. Borderie, M. Liard, M. Rué, C. Gibert. We also thank P. Dugas for her precious help in sample preparation, M. Corbé for field assistance, A. Tellez-Arenas for providing us the digitalised INSPIRE (1: 1,000,000) geological map of Europe and H. Patton for the reconstruction of the catchement area of the LGM Fleuve Manche and associated river network. We acknowledge the archaeologists who conducted the excavations and survey of Garons Mitra V, Soyons and Saint-Péray, particulary M. Laroche, J.-M. Lurol, B. Gely, J.-M. Le Pape, F. Derym. A. Delaunay made corrections and revisions that significantly improve the English language. All the results and data used in this study are presented in this manuscript and Supporting Information.

\section{References}

Adamová, M., Havlíček, P., Šibrava, V., 2002. Mineralogy and geochemistry of loesses in southern Moravia. Bull. Czech Geol. Survey 77, 29-41.

Aitchison, J., Greenacre, M., 2002. Biplots of compositional data. Journal of the Royal Statistical Society: Series C (Applied Statistics) 51, 375-392. https://doi.org/10.1111/1467-9876.00275

Alimen, H., 1965. Pétrographie des limons de Provence. Bulletin de l'Association Française pour l'Etude du Quaternaire 2, 35-65.

Altherr, R., Holl, A., Hegner, E., Langer, C., Kreuzer, H., 2000. High-potassium, calc-alkaline I-type plutonism in the European Variscides: northern Vosges (France) and northern Schwarzwald (Germany). Lithos 50, 51-73. https://doi.org/10.1016/S0024-4937(99)00052-3

Andreucci, S., Bateman, M.D., Zucca, C., Kapur, S., AkşIt, I., Dunajko, A., Pascucci, V., 2012. Evidence of Saharan dust in upper Pleistocene reworked palaeosols of North-west Sardinia, Italy: palaeoenvironmental implications: MIS 5 Saharan dust along the West Mediterranean basin. Sedimentology 59, 917-938. https://doi.org/10.1111/j.1365-3091.2011.01285.x

Andrieux, E., Bertran, P., Saito, K., 2016. Spatial analysis of the French Pleistocene permafrost by a GIS database. Permafrost and Periglacial Processes 27, 17-30.

Antoine, P., Rousseau, D.-D., Degeai, J.-P., Moine, O., Lagroix, F., kreutzer, S., Fuchs, M., Hatté, C., Gauthier, C., Svoboda, J., Lisá, L., 2013. High-resolution record of the environmental response to climatic variations during the Last Interglacial-Glacial cycle in Central Europe: the loess-palaeosol sequence of Dolní Věstonice (Czech Republic). Quaternary Science Reviews 67, 17-38. https://doi.org/10.1016/j.quascirev.2013.01.014

Antoine, P., Rousseau, D.-D., Moine, O., Kunesch, S., Hatté, C., Lang, A., Tissoux, H., Zöller, L., 2009. Rapid and cyclic aeolian deposition during the Last Glacial in European loess: a high-resolution record from Nussloch, Germany. Quaternary Science Reviews 28, 2955-2973. https://doi.org/10.1016/j.quascirev.2009.08.001 
Arnalds, O., Dagsson-Waldhauserova, P., Olafsson, H., 2016. The Icelandic volcanic aeolian environment: Processes and impacts - A review. Aeolian Research 20, 176-195. https://doi.org/10.1016/j.aeolia.2016.01.004

Asch, K., 2003. The 1:5 Million International Geological Map of Europe and Adjacent Areas: Development and Implementation of a GIS-enabled Concept. Hannover, Germany: Geologisches Jahrbuch.

Balescu, S., 1988. Apports de la thermoluminescence à la stratigraphie et à la sédimentologie des loess du Nord-Ouest de l'Europe. (Ph.D. Thesis). Université de Bruxelles 1, Belgium.

Bellanca, A., Masetti, D., Neri, R., 1997. Rare earth elements in limestone/marlstone couplets from the Albian-Cenomanian Cismon section (Venetian region, northern Italy): assessing REE sensitivity to environmental changes. Chemical Geology 141, 141-152. https://doi.org/10.1016/S00092541(97)00058-2

Bertran, P., Liard, M., Sitzia, L., Tissoux, H., 2016. A map of Pleistocene aeolian deposits in Western Europe, with special emphasis on France. Journal of Quaternary Science 31, e2909. https://doi.org/10.1002/jqs.2909

Billard, A., Derbyshire, E., 1985. Pleistocene stratigraphy and morphogenesis of La Dombes an alternative hypothesis. Bulletin de l'Association Française pour l'Etude du Quaternaire 22, 85-96. https://doi.org/10.3406/quate.1985.1532

Boixadera, J., Poch, R.M., Lowick, S.E., Balasch, J.C., 2015. Loess and soils in the eastern Ebro Basin. Quaternary International 376, 114-133. https://doi.org/10.1016/j.quaint.2014.07.046

Bösken, J., Obreht, I., Zeeden, C., Klasen, N., Hambach, U., Sümegi, P., Lehmkuhl, F., 2017. Highresolution paleoclimatic proxy data from the MIS3/2 transition recorded in northeastern Hungarian loess. Quaternary International 52, 95-107. https://doi.org/10.1016/j.quaint.2017.12.008

Bosq, M., Bertran, P., Degeai, J.-P., Kreutzer, S., Queffelec, A., Moine, O., Morin, E., 2018. Last Glacial aeolian landforms and deposits in the Rhône Valley (SE France): Spatial distribution and grainsize characterization. Geomorphology 318, 250-269. https://doi.org/10.1016/j.geomorph.2018.06.010

Bouchez, J., Gaillardet, J., Lupker, M., Louvat, P., France-Lanord, C., Maurice, L., Armijos, E., Moquet, J.-S., 2012. Floodplains of large rivers: Weathering reactors or simple silos? Chemical Geology 332-333, 166-184. https://doi.org/10.1016/j.chemgeo.2012.09.032

Bout-Roumazeilles, V., Combourieu Nebout, N., Peyron, O., Cortijo, E., Landais, A., MassonDelmotte, V., 2007. Connection between South Mediterranean climate and North African atmospheric circulation during the last 50,000yrBP North Atlantic cold events. Quaternary Science Reviews 26, 3197-3215. https://doi.org/10.1016/j.quascirev.2007.07.015

Bristow, C.S., Hudson-Edwards, K.A., Chappell, A., 2010. Fertilizing the Amazon and equatorial Atlantic with West African dust. Geophysical Research Letters 37. https://doi.org/10.1029/2010GL043486

Buggle, B., Glaser, B., Hambach, U., Gerasimenko, N., Marković, S., 2011. An evaluation of geochemical weathering indices in loess-paleosol studies. Quaternary International 240, 12-21. https://doi.org/10.1016/j.quaint.2010.07.019

Buggle, B., Glaser, B., Zöller, L., Hambach, U., Marković, S., Glaser, I., Gerasimenko, N., 2008. Geochemical characterization and origin of Southeastern and Eastern European loesses (Serbia, 
Romania, Ukraine). Quaternary Science Reviews 27, 1058-1075. https://doi.org/10.1016/j.quascirev.2008.01.018

Bullard, J.E., 2013. Contemporary glacigenic inputs to the dust cycle. Earth Surface Processes and Landforms 38, 71-89. https://doi.org/10.1002/esp.3315

Bullard, J.E., Austin, M.J., 2011. Dust generation on a proglacial floodplain, West Greenland. Aeolian Research 3, 43-54. https://doi.org/10.1016/j.aeolia.2011.01.002

Bullard, J.E., Mockford, T., 2018. Seasonal and decadal variability of dust observations in the Kangerlussuaq area, west Greenland. Arctic, Antarctic, and Alpine Research 50, S100011. https://doi.org/10.1080/15230430.2017.1415854

Buoncristiani, J.-F., Campy, M., 2011. Quaternary Glaciations in the French Alps and Jura, in: Elhers, J., Gibbard, P.L., Hughes, P.D. (Eds.), Quaternary Glaciations - Extent and Chronology: A Closer Look, Developments in Quaternary Science. Elsevier, Amsterdam, pp. 117-126. https://doi.org/10.1016/B978-0-444-53447-7.00010-6

Calvo, F.R., Sánchez, J., Acosta, A., Wolf, D., Faust, D., 2016. Granulometrical, mineralogical and geochemical characterization of loess deposits in the Tajo Basin. Quaternary International 407, 14-28.

Carignan, J., Hild, P., Mevelle, G., Morel, J., Yeghicheyan, D., 2001. Routine Analyses of Trace Elements in Geological Samples using Flow Injection and Low Pressure On-Line Liquid Chromatography Coupled to ICP-MS: A Study of Geochemical Reference Materials BR, DR-N, UBN, AN-G and GH. Geostandards Newsletter 25, 187-198. https://doi.org/10.1111/j.1751908X.2001.tb00595.x

Castillo, S., Moreno, T., Querol, X., Alastuey, A., Cuevas, E., Herrmann, L., Mounkaila, M., Gibbons, W., 2008. Trace element variation in size-fractionated African desert dusts. Journal of Arid Environments 72, 1034-1045. https://doi.org/10.1016/j.jaridenv.2007.12.007

Chauvel, C., Garçon, M., Bureau, S., Besnault, A., Jahn, B., Ding, Z., 2014. Constraints from loess on the $\mathrm{Hf}-\mathrm{Nd}$ isotopic composition of the upper continental crust. Earth and Planetary Science Letters 388, 48-58. https://doi.org/10.1016/j.epsl.2013.11.045

Comas, M., Thió-Henestrosa, S., 2011. CoDaPack 2.0: a stand-alone, multi-platform compositional software. Presented at the Proceedings of the $4^{\text {th }}$ International Workshop on Compositional Data Analysis, Girona, Spain, p. 10.

Condie, K.C., 1993. Chemical composition and evolution of the upper continental crust: Contrasting results from surface samples and shales. Chemical Geology 104, 1-37. https://doi.org/10.1016/00092541(93)90140-E

Courtin-Nomade, A., Rakotoarisoa, O., Bril, H., Grybos, M., Forestier, L., Foucher, F., Kunz, M., 2012. Weathering of Sb-rich mining and smelting residues: Insight in solid speciation and soil bacteria toxicity. Geochemistry, Antimony 72, 29-39. https://doi.org/10.1016/j.chemer.2012.02.004

Couzinié, S., Laurent, O., Poujol, M., Mintrone, M., Chelle-Michou, C., Moyen, J.-F., Bouilhol, P., Vezinet, A., Marko, L., 2017. Cadomian S-type granites as basement rocks of the Variscan belt (Massif Central, France): Implications for the crustal evolution of the north Gondwana margin. Lithos 286287, 16-34. https://doi.org/10.1016/j.lithos.2017.06.001 
Cullers, R.L., 2000. The geochemistry of shales, siltstones and sandstones of Pennsylvanian-Permian age, Colorado, USA: implications for provenance and metamorphic studies. Lithos 51, 181-203. https://doi.org/10.1016/S0024-4937(99)00063-8

Dèzes, P., Schmid, S.M., Ziegler, P.A., 2004. Evolution of the European Cenozoic Rift System: interaction of the Alpine and Pyrenean orogens with their foreland lithosphere. Tectonophysics 389, 1-33. https://doi.org/10.1016/j.tecto.2004.06.011

Dijkmans, J.W., Törnqvist, T.E., 1991. Modern periglacial eolian deposits and landforms in the Søndre Strømfjord area, West Greenland and their palaeoenvironmental implications. Meddelelser om Grønland. Geoscience 25, 3-39.

Dubar, M., 1979. I.-Les caractères sédimentologiques des terrasses fluviatiles et leur couverture limoneuse en Moyenne Durance. Bulletin de l'Association Française pour 1'Etude du Quaternaire 16, $109-120$.

Ehlers, J., Gibbard, P.L., 2004. Quaternary Glaciations - Extent and Chronology: Part I: Europe. Elsevier, Amsterdam.

Eyrolle, F., Radakovitch, O., Raimbault, P., Charmasson, S., Antonelli, C., Ferrand, E., Aubert, D., Raccasi, G., Jacquet, S., Gurriaran, R., 2012. Consequences of hydrological events on the delivery of suspended sediment and associated radionuclides from the Rhône River to the Mediterranean Sea. Journal of Soils and Sediments 12, 1479-1495. https://doi.org/10.1007/s11368-012-0575-0

Fedo, C.M., Nesbitt, H.W., Young, G.M., 1995. Unraveling the effects of potassium metasomatism in sedimentary rocks and paleosols, with implications for paleoweathering conditions and provenance. Geology 23, 921-924. https://doi.org/10.1130/0091-7613(1995)023<0921:UTEOPM>2.3.CO;2

Frechen, M., Oches, E.A., Kohfeld, K.E., 2003. Loess in Europe-mass accumulation rates during the Last Glacial Period. Quaternary Science Reviews 22, 1835-1857. https://doi.org/10.1016/S02773791(03)00183-5

Gallet, S., Jahn, B., Van Vliet-Lanoë, B., Dia, A., Rossello, E., 1998. Loess geochemistry and its implications for particle origin and composition of the upper continental crust. Earth and Planetary Science Letters 156, 157-172. https://doi.org/10.1016/S0012-821X(97)00218-5

Garrels, R.M., Mackenzie, F.T., 1971. Evolution of sedimentary rocks. W.W. Norton \& Company, Inc., New York.

Garzanti, E., Andó, S., France-Lanord, C., Censi, P., Vignola, P., Galy, V., Lupker, M., 2011. Mineralogical and chemical variability of fluvial sediments 2. Suspended-load silt (GangaBrahmaputra, Bangladesh). Earth and Planetary Science Letters 302, 107-120. https://doi.org/10.1016/j.epsl.2010.11.043

Garzanti, E., Andò, S., France-Lanord, C., Vezzoli, G., Censi, P., Galy, V., Najman, Y., 2010. Mineralogical and chemical variability of fluvial sediments: 1. Bedload sand (Ganga-Brahmaputra, Bangladesh). Earth and Planetary Science Letters 299, 368-381. https://doi.org/10.1016/j.eps1.2010.09.017

Goudie, A.S., 2013. Arid and Semi-Arid Geomorphology. Cambridge University Press, Cambridge.

Govindaraju, K., 1995. 1995 working values with confidence limits for twenty-six CRPG, ANRT and IWG-GIT geostandards. Geostandards Newsletter 19, 1-32. 
Granet, M., Chabaux, F., Stille, P., Dosseto, A., France-Lanord, C., Blaes, E., 2010. U-series disequilibria in suspended river sediments and implication for sediment transfer time in alluvial plains: The case of the Himalayan rivers. Geochimica et Cosmochimica Acta 74, 2851-2865. https://doi.org/10.1016/j.gca.2010.02.016

Granet, M., Chabaux, F., Stille, P., France-Lanord, C., Pelt, E., 2007. Time-scales of sedimentary transfer and weathering processes from U-series nuclides: Clues from the Himalayan rivers. Earth and Planetary Science Letters 261, 389-406. https://doi.org/10.1016/j.eps1.2007.07.012

Guo, Y., Yang, S., Su, N., Li, C., Yin, P., Wang, Z., 2018. Revisiting the effects of hydrodynamic sorting and sedimentary recycling on chemical weathering indices. Geochimica et Cosmochimica Acta 227, 48-63. https://doi.org/10.1016/j.gca.2018.02.015

Harnois, L., 1988. The CIW index: A new chemical index of weathering. Sedimentary Geology 55, 319-322. https://doi.org/10.1016/0037-0738(88)90137-6

Heier, K.S., Billings, G.K., 1970. Rubidium, in: Wedepohld, K.H. (Eds.), Handbook of Geochemistry. Springer, Berlin, pp. 37B1-37N1.

Hugenholtz, C.H., Wolfe, S.A., 2010. Rates and environmental controls of aeolian dust accumulation, Athabasca River Valley, Canadian Rocky Mountains. Geomorphology 121, 274-282. https://doi.org/10.1016/j.geomorph.2010.04.024

Jacq, V., Albert, P., Delorme, R., 2005. Le mistral, en 1925 et aujourd'hui: Le mistral-Quelques aspects des connaissances actuelles. La Météorologie 30-38.

Jamagne, M., 1973. Contribution à l'étude pédogénétique des formations loessiques du Nord de la France. (Ph.D. Thesis). Université de Liège, Belgium.

Joly, D., Brossard, T., Cardot, H., Cavailhes, J., Hilal, M., Wavresky, P., 2010. Les types de climats en France, une construction spatiale. Cybergeo: European Journal of Geography 501. https://doi.org/10.4000/cybergeo.23155

Juvigné, E., 1985. The use of heavy mineral suites for loess stratigraphy. Geologie en Mijnbouw 64, 333-336.

Juvigné, E., 1978. Les minéraux denses transparents des loess de Belgique. Zeitschrift für Geomorphologie NF 22, 68-88.

Kühn, P., Techmer, A., Weidenfeller, M., 2013. Lower to middle Weichselian pedogenesis and palaeoclimate in Central Europe using combined micromorphology and geochemistry: the loesspaleosol sequence of Alsheim (Mainz Basin, Germany). Quaternary Science Reviews 75, 43-58.

Kukla, G.J., 1977. Pleistocene land—sea correlations I. Europe. Earth-Science Reviews 13, 307-374.

Lafuente, B., Downs, R.T., Yang, H., Stone, N., 2016. The power of databases: the RRUFF project, in: Armbruster, T., Danisi, R.M. (Eds.), Highlights in Mineralogical Crystallography. Walter de Gruyter GmbH, Berlin, pp. 1-29.

Lautridou, J.P., 1985. Le cycle périglaciaire plèistocène en Europe du Nord-Ouest. (Ph.D. Thesis) University de Caen, France.

Lautridou, J.P., Sommé, J., Jamagne, M., 1984. Sedimentological, mineralogical and geochemical characteristics of the loesses of North-West France, in: Pécsi, M. (Eds.), Lithology and Stratigraphy 
of Loess and Paleosols. Geographical Research Institute of the Hungarian Academy of Sciences, Budapest, pp. 121-132.

Laxton, J., Serrano, J.-J., Tellez-Arenas, A., 2010. Geological applications using geospatial standards - an example from OneGeology-Europe and GeoSciML. International Journal of Digital Earth 3, 3149. https://doi.org/10.1080/17538941003636909

Lebret, P., Lautridou, J.-P., 1991. The loess of West Europe. GeoJournal 24, 151-156. https://doi.org/10.1007/BF00186010

Lehner, B., Grill, G., 2013. Global river hydrography and network routing: baseline data and new approaches to study the world's large river systems. Hydrological Processes 27, 2171-2186. https://doi.org/10.1002/hyp.9740

Liang, L., Sun, Y., Beets, C.J., Prins, M.A., Wu, F., Vandenberghe, J., 2013. Impacts of grain size sorting and chemical weathering on the geochemistry of Jingyuan loess in the northwestern Chinese Loess Plateau. Journal of Asian Earth Sciences 69, 177-184. https://doi.org/10.1016/j.jseaes.2012.12.015

Lin, Y., Mu, G., Xu, L., Zhao, X., 2016. The origin of bimodal grain-size distribution for aeolian deposits. Aeolian Research 20, 80-88. https://doi.org/10.1016/j.aeolia.2015.12.001

Lindner, H., Lehmkuhl, F., Zeeden, C., 2017. Spatial loess distribution in the eastern Carpathian Basin: a novel approach based on geoscientific maps and data. Journal of Maps 13, 173-181. https://doi.org/10.1080/17445647.2017.1279083

Mahowald, N.M., Muhs, D.R., Levis, S., Rasch, P.J., Yoshioka, M., Zender, C.S., Luo, C., 2006. Change in atmospheric mineral aerosols in response to climate: Last glacial period, preindustrial, modern, and doubled carbon dioxide climates. Journal of Geophysical Research 111, D10202. https://doi.org/10.1029/2005JD006653

Manatschal, G., Sauter, D., Karpoff, A.M., Masini, E., Mohn, G., Lagabrielle, Y., 2011. The Chenaillet Ophiolite in the French/Italian Alps: An ancient analogue for an Oceanic Core Complex? Lithos, Alpine Ophiolites and Modern Analogues 124, 169-184. https://doi.org/10.1016/j.lithos.2010.10.017

Mandier, P., 1984. Le relief de la moyenne vallée du Rhône au Tertiaire et au Quaternaire. Bulletin du laboratoire rhodanien de géomorphologie 27-36.

Marković, S.B., Stevens, T., Kukla, G.J., Hambach, U., Fitzsimmons, K.E., Gibbard, P., Buggle, B., Zech, M., Guo, Z., Hao, Q., Wu, H., O’Hara Dhand, K., Smalley, I.J., Újvári, G., Sümegi, P., TimarGabor, A., Veres, D., Sirocko, F., Vasiljević, D.A., Jary, Z., Svensson, A., Jović, V., Lehmkuhl, F., Kovács, J., Svirčev, Z., 2015. Danube loess stratigraphy — Towards a pan-European loess stratigraphic model. $\quad$ Earth-Science $\quad$ Reviews $148, \quad 228-258$. https://doi.org/10.1016/j.earscirev.2015.06.005

Martín-Fernández, J.A., Barceló-Vidal, C., Pawlowsky-Glahn, V., 2003. Dealing with zeros and missing values in compositional data sets using nonparametric imputation. Mathematical Geology 35, 253-278.

McDonough, W.F., Sun, S. -s., 1995. The composition of the Earth. Chemical Geology 120, 223-253. https://doi.org/10.1016/0009-2541(94)00140-4 
McLennan, S.M., 1989. Rare earth elements in sedimentary rocks: influence of provenance and sedimentary processes. Geochemistry and Mineralogy of Rare Earth Elements, Reviews in Mineralogy 21 169-200.

McLennan, S.M., 2001. Relationships between the trace element composition of sedimentary rocks and upper continental crust. Geochemistry, Geophysics, Geosystems 2, 203-236. https://doi.org/10.1029/2000GC000109

Mikulčić Pavlaković, S., Crnjaković, M., Tibljaš, D., Šoufek, M., Wacha, L., Frechen, M., Lacković, D., 2011. Mineralogical and geochemical characteristics of Quaternary sediments from the Island of Susak (Northern Adriatic, Croatia). Quaternary International 234, 32-49. https://doi.org/10.1016/j.quaint.2010.02.005

Moreno, T., Querol, X., Castillo, S., Alastuey, A., Cuevas, E., Herrmann, L., Mounkaila, M., Elvira, J., Gibbons, W., 2006. Geochemical variations in aeolian mineral particles from the Sahara-Sahel Dust Corridor. Chemosphere 65, 261-270. https://doi.org/10.1016/j.chemosphere.2006.02.052

Muhs, D.R., 2018. The geochemistry of loess: Asian and North American deposits compared. Journal of Asian Earth Sciences 155, 81-115. https://doi.org/10.1016/j.jseaes.2017.10.032

Muhs, D.R., Bettis III, E.A., 2003. Quaternary loess-paleosol sequences as examples of climate-driven sedimentary extremes. Geological Society of America 370, 53-74.

Muhs, D.R., Budahn, J., Avila, A., Skipp, G., Freeman, J., Patterson, D., 2010. The role of African dust in the formation of Quaternary soils on Mallorca, Spain and implications for the genesis of Red Mediterranean soils. Quaternary Science Reviews 29, 2518-2543. https://doi.org/10.1016/j.quascirev.2010.04.013

Muhs, D.R., Budahn, J.R., 2006. Geochemical evidence for the origin of late Quaternary loess in central Alaska. Canadian Journal of Earth Sciences 43, 323-337. https://doi.org/10.1139/e05-115

Nesbitt, H.W., Markovics, G., Price, R.C., 1980. Chemical processes affecting alkalis and alkaline earths during continental weathering. Geochimica et Cosmochimica Acta 44, 1659-1666. https://doi.org/10.1016/0016-7037(80)90218-5

Nesbitt, H.W., Young, G.M., 1982. Early Proterozoic climates and plate motions inferred from major element chemistry of lutites. Nature 299, 715. https://doi.org/10.1038/299715a0

Nesbitt, H.W., Young, G.M., 1989. Formation and Diagenesis of Weathering Profiles. The Journal of Geology 97, 129-147. https://doi.org/10.1086/629290

Nesbitt, H.W., Young, G.M., McLennan, S.M., Keays, R.R., 1996. Effects of Chemical Weathering and Sorting on the Petrogenesis of Siliciclastic Sediments, with Implications for Provenance Studies. The Journal of Geology 104, 525-542. https://doi.org/10.1086/629850

Obreht, I., Zeeden, C., Hambach, U., Veres, D., Marković, S.B., Bösken, J., Svirčev, Z., Bačević, N., Gavrilov, M.B., Lehmkuhl, F., 2016. Tracing the influence of Mediterranean climate on Southeastern Europe during the past 350,000 years. Scientific Reports 6, 36334. https://doi.org/10.1038/srep36334

[dataset] Obreht, I., Zeeden, C., Schulte, P., Hambach, U., Eckmeier, E., Timar-Gabor, A., Lehmkuhl, F., 2015. Textural and geochemical analyses of the Orlovat loess-paleosol sequence, northern Serbia. Supplement to: Obreht, I et al. (2015): Aeolian dynamics at the Orlovat loess-paleosol sequence, northern Serbia, based on detailed textural and geochemical evidence. Aeolian Research, 18, 69-81, https://doi.org/10.1594/PANGAEA.848686 
Olivier, J.-M., Dole-Olivier, M.-J., Amoros, C., Carrel, G., Malard, F., Lamouroux, N., Bravard, J.-P., 2009. Chapter 7 - The Rhône River Basin, in: Tockner, K., Uehlinger, U., Robinson, C.T. (Eds.), Rivers of Europe. Academic Press, London, pp. 247-295. https://doi.org/10.1016/B978-0-12-369449$2.00007-2$

Parks, D.A., Rendell, H.M., 1992. Thermoluminescence dating and geochemistry of loessic deposits in southeast England. Journal of Quaternary Science 7, 99-107.

Patton, H., Hubbard, A., Andreassen, K., Auriac, A., Whitehouse, P.L., Stroeven, A.P., Shackleton, C., Winsborrow, M., Heyman, J., Hall, A.M., 2017. Deglaciation of the Eurasian ice sheet complex. Quaternary Science Reviews 169, 148-172. https://doi.org/10.1016/j.quascirev.2017.05.019

Pirson, S., Baele, J.-M., Balescu, S., Haesaerts, P., Juvigné, E., Meijs, E., Spagna, P., 2018. Green amphibole distribution as a stratigraphic tool in loess sequences from Belgium: A review. Quaternary International 485, 183-198. https://doi.org/10.1016/j.quaint.2017.06.026

Porter, S.C., 2001. Chinese loess record of monsoon climate during the last glacial-interglacial cycle. Earth-Science Reviews 54, 115-128. https://doi.org/10.1016/S0012-8252(01)00043-5

Profe, J., Wacha, L., Frechen, M., Ohlendorf, C., Zolitschka, B., 2018. XRF scanning of discrete samples - A chemostratigraphic approach exemplified for loess-paleosol sequences from the Island of Susak, Croatia. Quaternary International 494, 34-51. https://doi.org/10.1016/j.quaint.2018.05.006

Profe, J., Zolitschka, B., Schirmer, W., Frechen, M., Ohlendorf, C., 2016. Geochemistry unravels MIS $3 / 2$ paleoenvironmental dynamics at the loess-paleosol sequence Schwalbenberg II, Germany. Palaeogeography, Palaeoclimatology, $\quad$ Palaeoecology $\quad 459, \quad 537-551$. https://doi.org/10.1016/j.palaeo.2016.07.022

Puaud, S., Nowak, M., Pont, S., Moncel, M.-H., 2015. Minéraux volcaniques et alpins à l'abri du Maras (Ardèche, France): témoins de vents catabatiques dans la vallée du Rhône au Pléistocène supérieur. Comptes Rendus Palevol 14, 331-341. https://doi.org/10.1016/j.crpv.2015.02.007

Pye, K., 1995. The nature, origin and accumulation of loess. Quaternary Science Reviews 14, 653667.

Raczyk, J., Jary, Z., Korabiewski, B., 2015. Geochemical properties of the Late Pleistocene loess-soil sequence in Dankowice (Niemcza-Strzelin Hills). Landform Analysis 29, 49-61.

Rantitsch, G., Melcher, F., Meisel, Th., Rainer, Th., 2003. Rare earth, major and trace elements in Jurassic manganese shales of the Northern Calcareous Alps: hydrothermal versus hydrogenous origin of stratiform manganese deposits. Mineralogy and Petrology 77, 109-127. https://doi.org/10.1007/s00710-002-0197-0

Reimann, C., Birke, M., Demetriades, A., Filzmoser, P., O’Connor, P., 2014. Part A: Chemistry of Europe's Agricultural Soils: Methodology and Interpretation of the GEMAS Data Set, Geologisches Jahrbuch, Hannover.

Römer, W., Lehmkuhl, F., Sirocko, F., 2016. Late Pleistocene aeolian dust provenances and wind direction changes reconstructed by heavy mineral analysis of the sediments of the Dehner dry maar (Eifel, Germany). Global and Planetary Change 147, 25-39. https://doi.org/10.1016/j.gloplacha.2016.10.012

Rousseau, D.-D., Chauvel, C., Sima, A., Hatté, C., Lagroix, F., Antoine, P., Balkanski, Y., Fuchs, M., Mellett, C., Kageyama, M., Ramstein, G., Lang, A., 2014. European glacial dust deposits: 
Geochemical constraints on atmospheric dust cycle modeling. Geophysical Research Letters 41, 76667674. https://doi.org/10.1002/2014GL061382

Rudnick, R.L., Gao, S., 2003. Composition of the Continental Crust. Treatise on Geochemistry 3, 659. https://doi.org/10.1016/B0-08-043751-6/03016-4

Ruth, U., Bigler, M., Röthlisberger, R., Siggaard-Andersen, M.-L., Kipfstuhl, S., Goto-Azuma, K., Hansson, M.E., Johnsen, S.J., Lu, H., Steffensen, J.P., 2007. Ice core evidence for a very tight link between North Atlantic and east Asian glacial climate. Geophysical Research Letters 34. https://doi.org/10.1029/2006GL027876

Salminen, R., Batista, M.J., Bidovec, M., Demetriades, A., De Vivo, B., De Vos, W., Duris, M., Gilucis, A., Gregorauskiene, V., Halamic, J., 2005. FOREGS Geochemical Atlas of Europe Part 1. Background Information, Methodology and Maps. Geological Survey of Finland, Espoo.

Sasco, R., Guillou, H., Nomade, S., Scao, V., Maury, R.C., Kissel, C., Wandres, C., 2017. 40Ar/39Ar and unspiked 40K-40Ar dating of upper Pleistocene volcanic activity in the Bas-Vivarais (Ardèche, France). Journal of Volcanology and Geothermal Research 341, 301-314. https://doi.org/10.1016/j.jvolgeores.2017.06.003

Schatz, A.-K., Qi, Y., Siebel, W., Wu, J., Zöller, L., 2015. Tracking potential source areas of Central European loess: examples from Tokaj (HU), Nussloch (D) and Grub (AT). Open Geosciences 7, 678720. https://doi.org/10.1515/geo-2015-0048

Scheib, A., Lee, J.R., 2010. The application of regional-scale geochemical data in defining the extent of aeolian sediments: the Late Pleistocene loess and coversand deposits of East Anglia, UK. Quaternary newsletter 120, 5-14.

Scheib, A.J., Birke, M., Dinelli, E., GEMAS Project Team, 2014. Geochemical evidence of aeolian deposits in European soils: Geochemical evidence of aeolian deposits in European soils. Boreas 43, 175-192. https://doi.org/10.1111/bor.12029

Scheib, A.J., Flight, D.M.A., Birke, M., Tarvainen, T., Locutura, J., GEMAS Project Team, 2012. The geochemistry of niobium and its distribution and relative mobility in agricultural soils of Europe. Geochemistry: Exploration, Environment, Analysis 12, 293-302. https://doi.org/10.1144/geochem2011-096

Scheuvens, D., Schütz, L., Kandler, K., Ebert, M., Weinbruch, S., 2013. Bulk composition of northern African dust and its source sediments — A compilation. Earth-Science Reviews 116, 170-194. https://doi.org/10.1016/j.earscirev.2012.08.005

Seelos, K., Sirocko, F., Dietrich, S., 2009. A continuous high-resolution dust record for the reconstruction of wind systems in central Europe (Eifel, Western Germany) over the past $133 \mathrm{ka}$. Geophysical Research Letters 36. https://doi.org/10.1029/2009GL039716

Seguinot, J., Ivy-Ochs, S., Jouvet, G., Huss, M., Funk, M., Preusser, F., 2018. Modelling last glacial cycle ice dynamics in the Alps. The Cryosphere 12, 3265-3285. https://doi.org/10.3929/ethz-b000297918

Simeon, Y., 1979. Etude pétrologique, géochimique et structurale des terrains cristallins de Belledonne entre l'Arc et l'Isère (Alpes françaises). (Ph.D. Thesis). Université scientifique et médicale de Grenoble, France. 
Sitzia, L., Bertran, P., Sima, A., Chery, P., Queffelec, A., Rousseau, D.-D., 2017. Dynamics and sources of last glacial aeolian deposition in southwest France derived from dune patterns, grain-size gradients and geochemistry, and reconstruction of efficient wind directions. Quaternary Science Reviews 170, 250-268. https://doi.org/10.1016/j.quascirev.2017.06.029

Sitzia, L., Gayo, E.M., Sepulveda, M., González, J.S., Ibañez, L., Queffelec, A., Pol-Holz, R.D., 2019. A perched, high-elevation wetland complex in the Atacama Desert (northern Chile) and its implications for past human settlement. Quaternary Research 92, 33-52. https://doi.org/10.1017/qua.2018.144

Sivan, O., Flambeaux, A., Landure, C., Taras, M., Voyez, C., 2018. Découverte d'une nouvelle séquence lacustre du pléistocène supérieur à Saint-Maximin-la-Sainte-Baume (Var, France) : un important potentiel pour l'étude multi-indicateurs des changements environnementaux en Provence. Quaternaire. Revue de l'Association Française pour l'Etude du Quaternaire 29, 363-373. https://doi.org/10.4000/quaternaire.10645

Skurzyński, J., Jary, Z., Raczyk, J., Moska, P., Korabiewski, B., Ryzner, K., Krawczyk, M., 2019. Geochemical characterization of the Late Pleistocene loess-palaeosol sequence in Tyszowce (Sokal Plateau-Ridge, SE Poland). Quaternary International 502, 108-118.

Skurzyński, J., Jary, Z., Raczyk, J., Moska, P., Krawczyk, M., 2017. Stratygraficzne i przestrzenne aspekty zróżnicowania składu chemicznego późnoplejstoceńskich sekwencji lessowo-glebowych w Polsce-przykłady profili w Tyszowcach i Białym Kościele. Acta Geographica Lodziensia 106, 87103.

Smalley, I., O’Hara-Dhand, K., Wint, J., Machalett, B., Jary, Z., Jefferson, I., 2009. Rivers and loess: The significance of long river transportation in the complex event-sequence approach to loess deposit formation. Quaternary International 198, 7-18. https://doi.org/10.1016/j.quaint.2008.06.009

Smykatz-Kloss, B., 2003. Die Lößvorkommen des Pleiser Hügellandes bei Bonn und von Neustadt, Wied sowie der Picardie: mineralogisch-geochemische und geomorphologische Charakterisierung, Verwitterungs-Beeinflussung und Herkunft der Lösse. (Ph. D. Thesis). Rheinischen FriedrichWilhelms-Universität Bonn, Germany.

Steinmann, M., Stille, P., 2008. Controls on transport and fractionation of the rare earth elements in stream water of a mixed basaltic-granitic catchment basin (Massif Central, France). Chemical Geology 254, 1-18. https://doi.org/10.1016/j.chemgeo.2008.04.004

Stevens, T., Marković, S.B., Zech, M., Hambach, U., Sümegi, P., 2011. Dust deposition and climate in the Carpathian Basin over an independently dated last glacial-interglacial cycle. Quaternary Science Reviews 30, 662-681. https://doi.org/10.1016/j.quascirev.2010.12.011

Sun, J., Li, S.-H., Muhs, D.R., Li, B., 2007. Loess sedimentation in Tibet: provenance, processes, and link with Quaternary glaciations. Quaternary Science Reviews 26, 2265-2280. https://doi.org/10.1016/j.quascirev.2007.05.003

Sweeney, M.R., Mason, J.A., 2013. Mechanisms of dust emission from Pleistocene loess deposits, Nebraska, USA. Journal of Geophysical Research: Earth Surface 118, 1460-1471. https://doi.org/10.1002/jgrf.20101

Taylor, S.R., McLennan, S.M., 1985. The continental crust: Its composition and evolution. Blackwell, Oxford. 
Taylor, S.R., McLennan, S.M., McCulloch, M.T., 1983. Geochemistry of loess, continental crustal composition and crustal model ages. Geochimica et Cosmochimica Acta 47, 1897-1905. https://doi.org/10.1016/0016-7037(83)90206-5

Tsoar, H., Pye, K., 1987. Dust transport and the question of desert loess formation. Sedimentology 34, $139-153$.

Újvári, G., Varga, A., Balogh-Brunstad, Z., 2008. Origin, weathering, and geochemical composition of loess in southwestern Hungary. Quaternary Research 69, 421-437. https://doi.org/10.1016/j.yqres.2008.02.001

Újvári, G., Varga, A., Raucsik, B., Kovács, J., 2014. The Paks loess-paleosol sequence: A record of chemical weathering and provenance for the last 800ka in the mid-Carpathian Basin. Quaternary International 319, 22-37. https://doi.org/10.1016/j.quaint.2012.04.004

Varga, G., Kovács, J., Újvári, G., 2013. Analysis of Saharan dust intrusions into the Carpathian Basin (Central Europe) over the period of 1979-2011. Global and Planetary Change 100, 333-342. https://doi.org/10.1016/j.gloplacha.2012.11.007

von Eynatten, H., 2003. Petrography and chemistry of sandstones from the Swiss Molasse Basin: an archive of the Oligocene to Miocene evolution of the Central Alps. Sedimentology 50, 703-724. https://doi.org/10.1046/j.1365-3091.2003.00571.x

von Eynatten, H., Tolosana-Delgado, R., Karius, V., 2012. Sediment generation in modern glacial settings: Grain-size and source-rock control on sediment composition. Sedimentary Geology 280, 80 92. https://doi.org/10.1016/j.sedgeo.2012.03.008

Wacha, L., Rolf, C., Hambach, U., Frechen, M., Galović, L., Duchoslav, M., 2018. The Last Glacial aeolian record of the Island of Susak (Croatia) as seen from a high-resolution grain-size and rock magnetic analysis. Quaternary International 494, 211-224. https://doi.org/10.1016/j.quaint.2017.08.016

Waroszewski, J., Sprafke, T., Kabala, C., Musztyfaga, E., Łabaz, B., Woźniczka, P., 2018. Aeolian silt contribution to soils on mountain slopes (Mt. Ślęża, southwest Poland). Quaternary Research 89, 702717.

Wilson, M.J., 2013. Rock-Forming Minerals. Sheet Silicates: Clay Minerals, The Geological Society of London, London.

Wolf, D., Ryborz, K., Kolb, T., Zapata, R.C., Vizcaino, J.S., Zöller, L., Faust, D., 2019. Origins and genesis of loess deposits in central Spain, as indicated by heavy mineral compositions and grain-size variability. Sedimentology 66, 1139-1161. https://doi.org/10.1111/sed.12539

Wright, J.S., 2001. "Desert" loess versus "glacial" loess: quartz silt formation, source areas and sediment pathways in the formation of loess deposits. Geomorphology 36, 231-256. https://doi.org/10.1016/S0169-555X(00)00060-X

Wronkiewicz, D.J., Condie, K.C., 1990. Geochemistry and mineralogy of sediments from the Ventersdorp and Transvaal Supergroups, South Africa: Cratonic evolution during the early Proterozoic. Geochimica et Cosmochimica Acta 54, 343-354. https://doi.org/10.1016/00167037(90)90323-D

Zangana, N.A., Downes, H., Thirlwall, M.F., Marriner, G.F., Bea, F., 1999. Geochemical variation in peridotite xenoliths and their constituent clinopyroxenes from Ray Pic (French Massif Central): 
implications for the composition of the shallow lithospheric mantle. Chemical Geology 153, 11-35. https://doi.org/10.1016/S0009-2541(98)00150-8

Ziegler, P.A., Dèzes, P., 2007. Cenozoic uplift of Variscan Massifs in the Alpine foreland: Timing and controlling mechanisms. Global and Planetary Change 58, 237-269. https://doi.org/10.1016/j.gloplacha.2006.12.004 


\section{Geochemical signature of sources, recycling and weathering in the Last Glacial loess from the Rhône Valley (southeast France) and comparison with other European regions}

Mathieu Bosq ${ }^{1, *}$, Pascal Bertran ${ }^{1,2}$, Jean-Philippe Degeai $^{3}$, Alain Queffelec $^{1}$, and Olivier Moine ${ }^{4}$

${ }^{1}$ PACEA, UMR 5199 CNRS - Université Bordeaux, Bâtiment B2, allée Geoffroy Saint Hilaire, 33615 Pessac, France

${ }^{2}$ Inrap, 140 avenue du Maréchal Leclerc, 33130 Bègles, France

${ }^{3}$ ASM, UMR 5140 CNRS - Université de Montpellier III, route de Mende, 34199 Montpellier, France

${ }^{4}$ LGP, UMR 8591 CNRS - Université Paris I Panthéon-Sorbonne/Université Paris-Est-Créteil-Valde-Marne (UPEC), place Aristide Briand, 92195 Meudon, France

*Corresponding author: Mathieu Bosq (mathieu.bosq@gmail.com)

\section{Supplementary figures}

Fig. A1: ED-XRF calibration.

Fig. A2: Example of spectra obtained by RAMAN microspectrometer SENTERRA.

Fig. A3: Box plot of CPA index (A) and $\mathrm{Eu} / \mathrm{Eu}^{*}(\mathrm{~B})$ of loess deposits grouped by regions. 


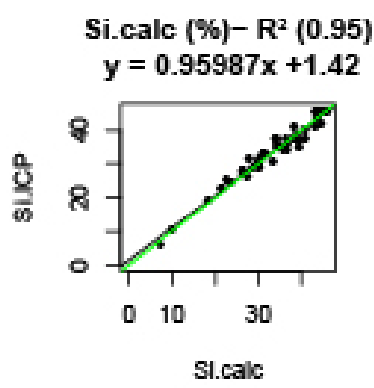

V.calc (ppm)- $\mathrm{R}^{2}$ (0.95) $y=0.87063 x+30.43$

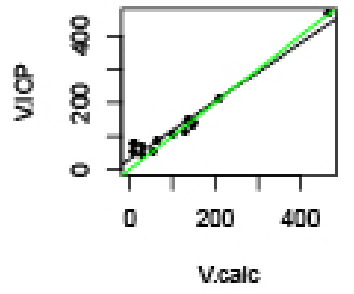

Zn.calc (ppm)- $\mathbf{R}^{2}$ (0.95) $y=1.01346 x+0.67$

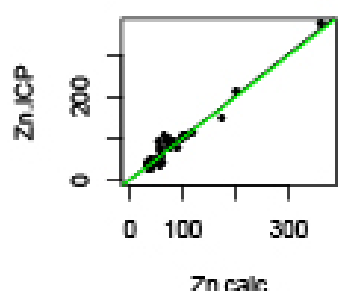

Sr.calc (ppm)- $\mathbf{R}^{2}(0.97)$ $y=0.98633 x+5.76$

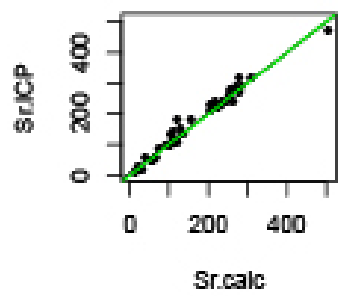

Pb.calc (ppm)- $\mathbf{R}^{2}(0.65)$ $y=1.10365 x+-0.85$

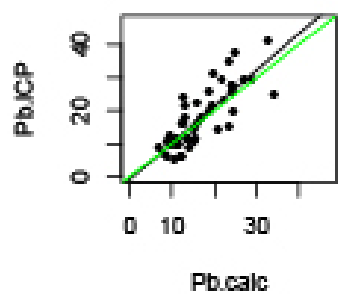

K.calc (\%)- $\mathrm{R}^{2}(0.94)$ $y=1.02856 x+-0.03$

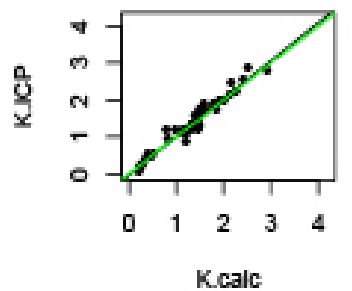

Cr.calc (ppm)- $\mathrm{R}^{2}$ (0.78) $y=0.90417 x+10.63$

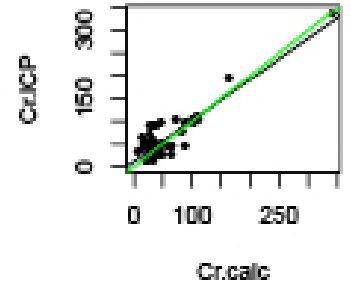

Ga.calc (ppm)- $R^{2}(0.89)$ $y=0.99519 x+0.07$

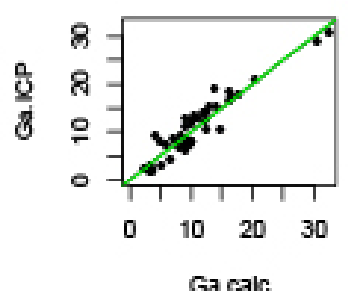

Y.calc (ppm)- $R^{2}(0.96)$ $y=0.97793 x+0.83$

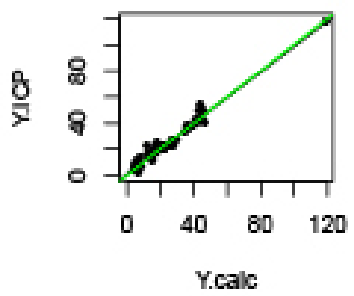

Th.calc (ppm)- $\mathrm{R}^{2}(0.83)$ $y=1.00673 x+0.87$

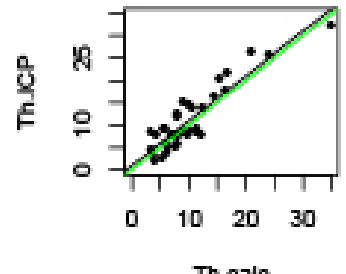

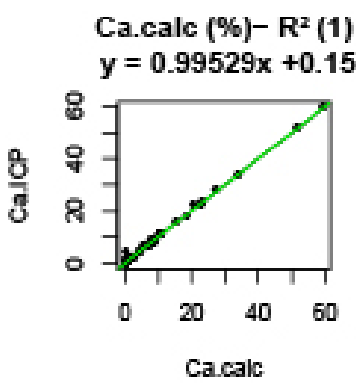

Mn.calc (\%)- $\mathrm{R}^{2}(0.97)$ $y=1.00432 x+0$

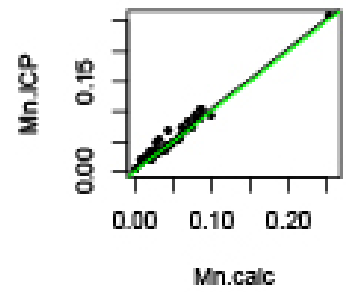

As.calc (ppm)- $\mathbf{R}^{2}(0.99)$ $y=0.99962 x+0.02$

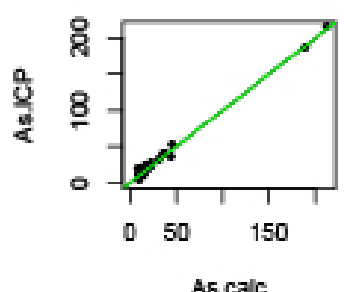

Zr.calc (ppm)- $\mathrm{R}^{2}(0.82)$ $y=0.99088 x+5.18$

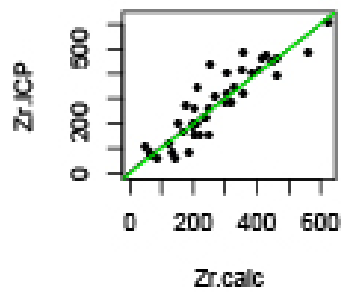

Ti.calc (\%)- $\mathbf{R}^{2}$ (0.97) $y=0.97512 x+0.01$

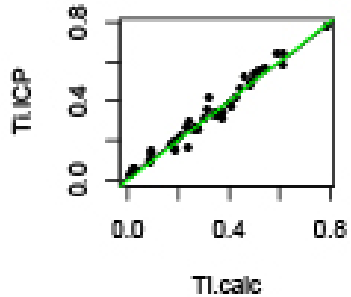

Fe.calc (\%)- $\mathrm{R}^{2}(0.99)$ $y=0.99528 x+0.05$

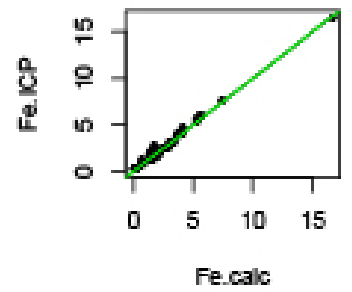

Rb.calc (ppm)- $\mathrm{R}^{2}(0.97)$ $y=0.99879 x+0.23$

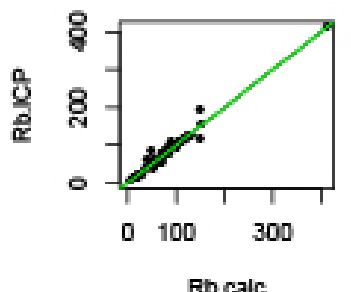

Ba.calc (ppm)- $\mathrm{R}^{2}$ (0.76) $y=1.00769 x+1.98$

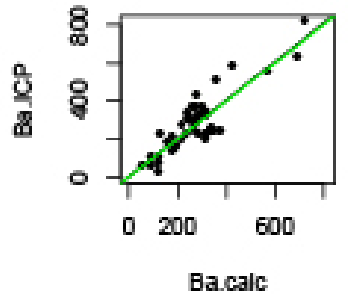

Fig. A1: Energy-Dispersive X-Ray Fluorescence (ED-XRF) data were obtained on pressed pellets made of $97 \%$ of ground sediment and 3\% of specific XRF wax, with acquisition parameters set to 40 $\mathrm{kV}, 50 \mu \mathrm{A}$ and $300 \mathrm{~s}$ of counting time. Elements lighter than $\mathrm{Si}$ are not detected with this device. Quantitative results are provided for 18 elements ( $\mathrm{Si}, \mathrm{K}, \mathrm{Ca}, \mathrm{Ti}, \mathrm{V}, \mathrm{Cr}, \mathrm{Mn}, \mathrm{Fe}, \mathrm{Zn}, \mathrm{Ga}, \mathrm{As}, \mathrm{Rb}, \mathrm{Sr}, \mathrm{Y}$, $\mathrm{Zr}, \mathrm{Ba}, \mathrm{Pb}, \mathrm{Th}$ ) following an empirical calibration based on the Lucas-Tooth and Price (1961) method, using the ICP-AES/ICP-MS composition of 46 samples of loess and surficial sediments measured at 
the SARM-CRPG (Carignan et al., 2001). Only elements with a coefficient of determination ( $\mathrm{R}^{2}$ ) equal or greater than 0.7 between ED-XRF and ICP-AES/ICP-MS values were considered.
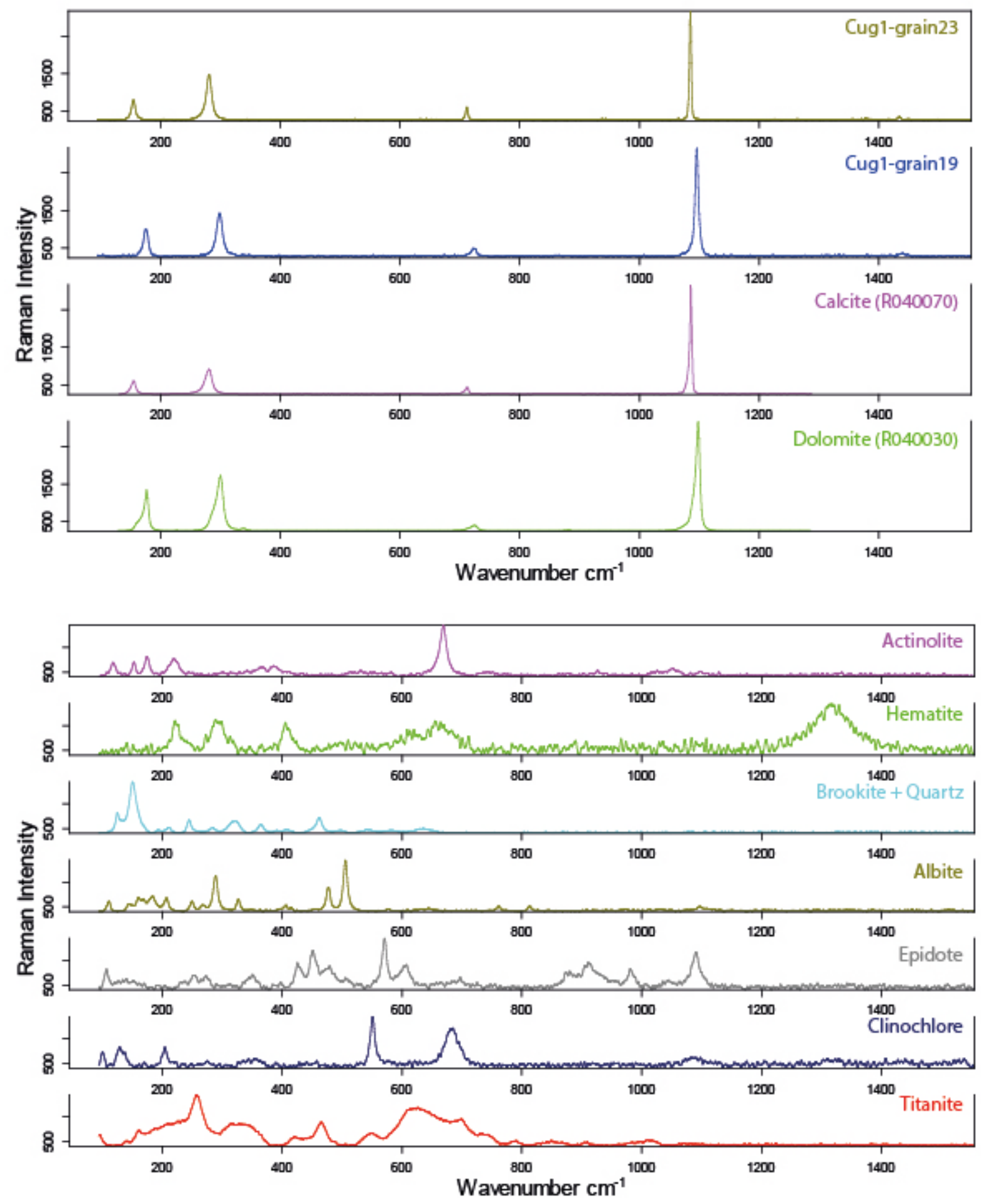

Fig. A2: Example of spectra obtained by RAMAN microspectrometer SENTERRA. 

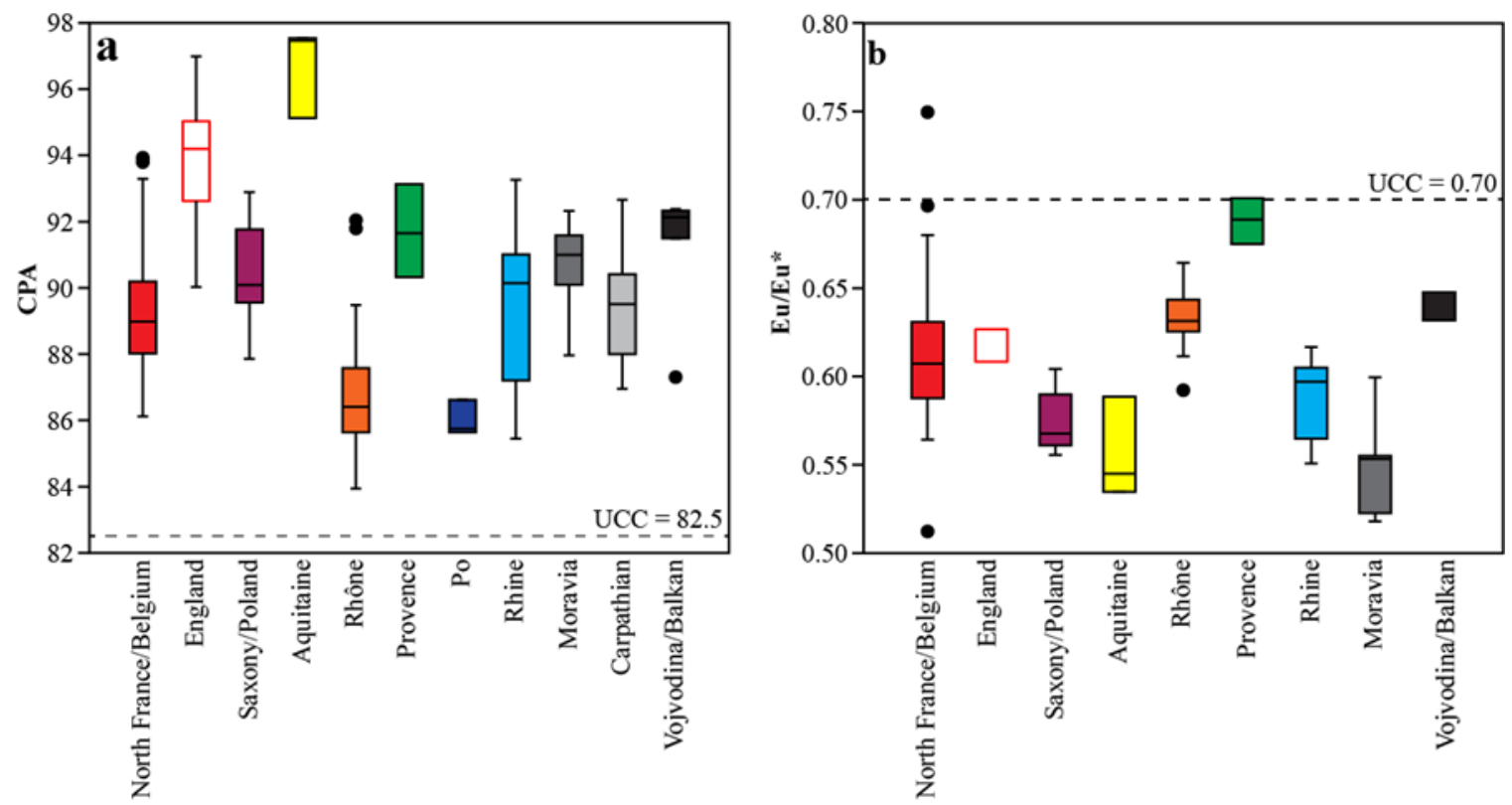

Fig. A3: Box plot of CPA index (a) and $\mathrm{Eu} / \mathrm{Eu}^{*}(\mathrm{~b})$ of loess deposits grouped by regions.

\section{References}

Carignan, J., Hild, P., Mevelle, G., Morel, J., Yeghicheyan, D., 2001. Routine Analyses of Trace Elements in Geological Samples using Flow Injection and Low Pressure On-Line Liquid Chromatography Coupled to ICP-MS: A Study of Geochemical Reference Materials BR, DRN, UB-N, AN-G and GH. Geostandards Newsletter 25, 187-198. https://doi.org/10.1111/j.1751-908X.2001.tb00595.x

Lucas-Tooth, H.J., Price, B.J., 1961. A mathematical method for investigation of inter-element effects in X-ray fluorescent analysis. Metallurgia 64, 149-161. 


\section{Supplementary tables}

Table A1: New major (wt \%) and trace element (ppm) data obtained by ICP analysis on the loess, palaeosols and potential sources samples.

Table A2: New major (wt \%) and trace element (ppm) data obtained by ED-XRF analysis on the Dombes loess.

Table A3: Box plot of CPA index (A) and $\mathrm{Eu} / \mathrm{Eu}^{*}(\mathrm{~B})$ of loess deposits grouped by regions. 


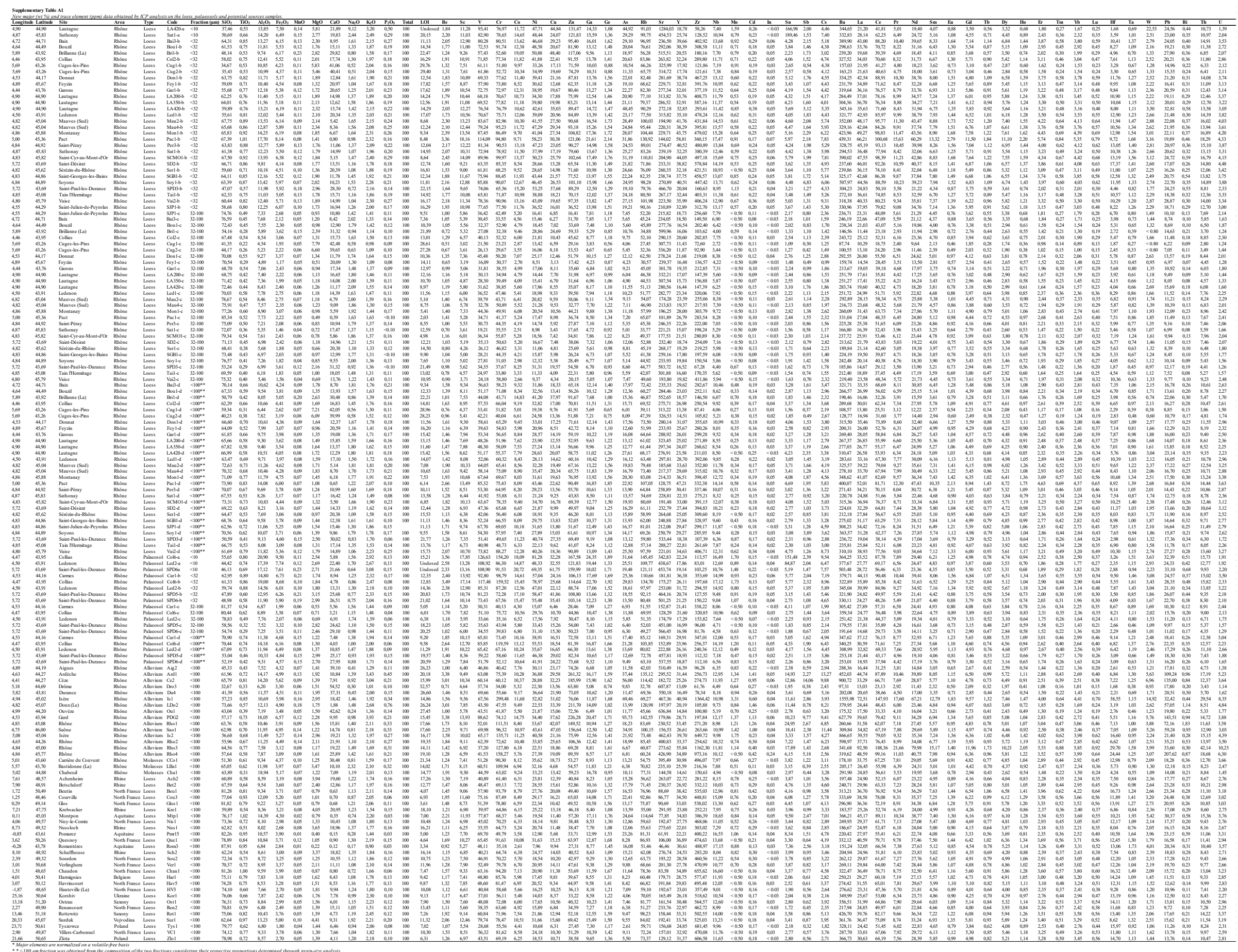




\section{Supplementary Table}

New major (wt \%) and trace element (ppm) data obtained by ED-XRF analysis on the Dombes loess.

\begin{tabular}{|c|c|c|c|c|c|c|c|c|c|c|c|c|c|c|c|c|c|c|c|c|c|c|c|c|}
\hline $\begin{array}{l}\text { Longitu } \\
\text { de }\end{array}$ & $\begin{array}{l}\text { Latitu } \\
\text { de }\end{array}$ & Site & $\begin{array}{l}\text { Are } \\
\text { a }\end{array}$ & Type & $\begin{array}{l}\text { Cod } \\
\text { e }\end{array}$ & $\begin{array}{l}\text { Fraction } \\
(\mu \mathrm{m})\end{array}$ & $\begin{array}{l}\mathrm{SiO} \\
2\end{array}$ & $\begin{array}{l}\mathrm{Ti} \\
\mathrm{O}_{2}\end{array}$ & $\begin{array}{l}\mathrm{Fe}_{2} \\
\mathrm{O}_{3}\end{array}$ & $\begin{array}{l}\text { Mn } \\
\text { O }\end{array}$ & $\begin{array}{l}\text { Ca } \\
\text { O }\end{array}$ & $\begin{array}{l}\mathbf{K}_{2} \\
\mathbf{O}\end{array}$ & $\mathbf{V}$ & $\mathrm{Cr}$ & $\mathbf{Z n}$ & $\mathbf{G a}$ & As & $\mathbf{R b}$ & $\mathrm{Sr}$ & $\mathbf{Y}$ & $\mathrm{Zr}$ & $\mathbf{B a}$ & $\mathbf{P b}$ & Th \\
\hline 4.78 & 605 & Domb & Saôn & Dacalcified & TA1- & $<32$ & $\begin{array}{l}76,2 \\
2\end{array}$ & $\begin{array}{l}0,8 \\
5\end{array}$ & 5.82 & $\begin{array}{l}0,0 \\
4\end{array}$ & $\begin{array}{l}2,2 \\
6\end{array}$ & $\begin{array}{l}2,0 \\
3\end{array}$ & $\begin{array}{l}68,5 \\
0\end{array}$ & $\begin{array}{l}39, \\
90\end{array}$ & $\begin{array}{l}79,9 \\
0\end{array}$ & $\begin{array}{l}14, \\
20\end{array}$ & 25, & $\begin{array}{l}117, \\
00\end{array}$ & $\begin{array}{l}171, \\
40\end{array}$ & $\begin{array}{l}41, \\
60\end{array}$ & $\begin{array}{l}368, \\
80\end{array}$ & $\begin{array}{l}498, \\
00\end{array}$ & $\begin{array}{l}13, \\
50\end{array}$ & $\begin{array}{l}13, \\
90\end{array}$ \\
\hline & & Domb & Saôn & Dacalcified & TA3- & & 78,0 & 0,7 & & 0,0 & 0,6 & 0,7 & & 11 , & 42,0 & 15 & 20 & 39,7 & 136 , & 51 , & 329, & & & 9,3 \\
\hline 4,90 & 46,01 & es & $\mathrm{e}$ & loess & $\mathrm{b}$ & $<32$ & 8 & 9 & 2,52 & 2 & 2 & 8 & - & 00 & 0 & 00 & 1 & 0 & 00 & 40 & 00 & - & - & 0 \\
\hline & & Domb & Saôn & Dacalcified & TA5- & & 88,8 & 0,8 & & 0,0 & 0,6 & 1,3 & 35,8 & 42 , & 58,5 & 9,0 & 12 & 90,0 & 135 & 40 , & 308 , & 433 & 13, & 12 , \\
\hline 5,09 & 45,98 & es & $\mathrm{e}$ & loess & $\mathrm{b}$ & $<32$ & 2 & 1 & 3,27 & 3 & 0 & 6 & 0 & 60 & 0 & 0 & 5 & 0 & 50 & 60 & 50 & 00 & 70 & 20 \\
\hline 5,22 & 46,00 & $\begin{array}{l}\text { Domb } \\
\text { es }\end{array}$ & $\begin{array}{l}\text { Saôn } \\
\text { e }\end{array}$ & $\begin{array}{l}\text { Dacalcified } \\
\text { loess }\end{array}$ & $\begin{array}{l}\text { TA7- } \\
\mathrm{b}\end{array}$ & $<32$ & $\begin{array}{l}85,5 \\
3\end{array}$ & $\begin{array}{l}0,8 \\
3\end{array}$ & 4,65 & $\begin{array}{l}0,0 \\
2\end{array}$ & $\begin{array}{l}0,5 \\
4\end{array}$ & $\begin{array}{l}1,5 \\
4\end{array}$ & $\begin{array}{l}51,0 \\
0\end{array}$ & $\begin{array}{l}58, \\
30\end{array}$ & $\begin{array}{l}67,1 \\
0\end{array}$ & $\begin{array}{l}10 \\
90\end{array}$ & $\begin{array}{l}14, \\
9\end{array}$ & $\begin{array}{l}100, \\
50\end{array}$ & $\begin{array}{l}136 \\
50\end{array}$ & $\begin{array}{l}37, \\
20\end{array}$ & $\begin{array}{l}329, \\
90\end{array}$ & $\begin{array}{l}514, \\
00\end{array}$ & $\begin{array}{l}13, \\
20\end{array}$ & $\begin{array}{l}9,1 \\
0\end{array}$ \\
\hline 4,90 & 46,16 & $\begin{array}{l}\text { Domb } \\
\text { es }\end{array}$ & $\begin{array}{l}\text { Saôn } \\
\text { e }\end{array}$ & $\begin{array}{l}\text { Dacalcified } \\
\text { loess }\end{array}$ & $\begin{array}{l}\text { TB2- } \\
\mathrm{b}\end{array}$ & $<32$ & $\begin{array}{l}81,7 \\
6\end{array}$ & $\begin{array}{l}0,8 \\
2\end{array}$ & 5,92 & $\begin{array}{l}0,0 \\
3\end{array}$ & $\begin{array}{l}0,6 \\
5\end{array}$ & $\begin{array}{l}1,6 \\
4\end{array}$ & $\begin{array}{l}71,9 \\
0\end{array}$ & $\begin{array}{l}47, \\
90\end{array}$ & $\begin{array}{l}84,6 \\
0\end{array}$ & $\begin{array}{l}13, \\
50\end{array}$ & $\begin{array}{l}21, \\
7\end{array}$ & $\begin{array}{l}118, \\
10\end{array}$ & $\begin{array}{l}156, \\
30\end{array}$ & $\begin{array}{l}42, \\
80\end{array}$ & $\begin{array}{l}382, \\
50\end{array}$ & $\begin{array}{l}541, \\
00\end{array}$ & $\begin{array}{l}12, \\
80\end{array}$ & $\begin{array}{l}15, \\
00\end{array}$ \\
\hline 5,11 & 45,90 & $\begin{array}{l}\text { Domb } \\
\text { es }\end{array}$ & $\begin{array}{l}\text { Saôn } \\
\text { e }\end{array}$ & $\begin{array}{l}\text { Dacalcified } \\
\text { loess }\end{array}$ & $\begin{array}{l}\text { TC5- } \\
b\end{array}$ & $<32$ & $\begin{array}{l}80,6 \\
3\end{array}$ & $\begin{array}{l}0,8 \\
1\end{array}$ & 6,52 & $\begin{array}{l}0,0 \\
4\end{array}$ & $\begin{array}{l}0,7 \\
9\end{array}$ & $\begin{array}{l}1,7 \\
8\end{array}$ & $\begin{array}{l}89,1 \\
0\end{array}$ & $\begin{array}{l}47, \\
30\end{array}$ & $\begin{array}{l}73,0 \\
0\end{array}$ & $\begin{array}{l}14, \\
30\end{array}$ & $\begin{array}{l}21, \\
2\end{array}$ & $\begin{array}{l}110, \\
50\end{array}$ & $\begin{array}{l}154, \\
00\end{array}$ & $\begin{array}{l}43, \\
70\end{array}$ & $\begin{array}{l}333, \\
90\end{array}$ & $\begin{array}{l}437, \\
00\end{array}$ & $\begin{array}{l}7,3 \\
0\end{array}$ & $\begin{array}{l}13, \\
90\end{array}$ \\
\hline 4,89 & 44,89 & $\begin{array}{l}\text { Domb } \\
\text { es }\end{array}$ & $\begin{array}{l}\text { Saôn } \\
\text { e }\end{array}$ & $\begin{array}{l}\text { Dacalcified } \\
\text { loess }\end{array}$ & $\begin{array}{l}\text { TD1- } \\
\mathrm{b}\end{array}$ & $<32$ & $\begin{array}{l}71,3 \\
9\end{array}$ & $\begin{array}{l}0,8 \\
2\end{array}$ & 8,44 & $\begin{array}{l}0,1 \\
6\end{array}$ & $\begin{array}{l}1,1 \\
0\end{array}$ & $\begin{array}{l}2,0 \\
6\end{array}$ & $\begin{array}{l}113, \\
70\end{array}$ & $\begin{array}{l}78, \\
90\end{array}$ & $\begin{array}{l}131, \\
30\end{array}$ & $\begin{array}{l}19, \\
20\end{array}$ & $\begin{array}{l}30 \\
5\end{array}$ & $\begin{array}{l}115, \\
80\end{array}$ & $\begin{array}{l}159 \\
80\end{array}$ & $\begin{array}{l}45 \\
70\end{array}$ & $\begin{array}{l}384, \\
90\end{array}$ & $\begin{array}{l}90,5 \\
0\end{array}$ & $\begin{array}{l}18, \\
20\end{array}$ & $\begin{array}{l}19, \\
40\end{array}$ \\
\hline & & Domb & Saôn & Dacalcified & TA1- & & 91,5 & 0,4 & & 0,0 & 1,4 & 1,4 & & 20 & & 6,9 & 10 & 60,9 & 118 & 14 , & 431 , & 354 , & 4,9 & 2,6 \\
\hline 4,78 & 46,05 & $\begin{array}{l}\text { es } \\
\text { Domb }\end{array}$ & $\begin{array}{l}\text { e } \\
\text { Saôn }\end{array}$ & $\begin{array}{l}\text { loess } \\
\text { Dacalcified }\end{array}$ & $\begin{array}{l}\mathrm{c} \\
\text { TA3- }\end{array}$ & $32-100$ & $\begin{array}{l}0 \\
94,4\end{array}$ & $\begin{array}{l}5 \\
0,4\end{array}$ & 1,79 & $\begin{array}{l}3 \\
0,0\end{array}$ & $\begin{array}{l}5 \\
0,5\end{array}$ & $\begin{array}{l}4 \\
1,0\end{array}$ & - & 30 & - & $\begin{array}{l}0 \\
4,7\end{array}$ & 7 & & $\begin{array}{l}70 \\
106\end{array}$ & $\begin{array}{l}70 \\
15\end{array}$ & $\begin{array}{l}30 \\
472\end{array}$ & $\begin{array}{l}00 \\
401,\end{array}$ & $\begin{array}{l}0 \\
8,2\end{array}$ & $\begin{array}{l}0 \\
2,7\end{array}$ \\
\hline 4,90 & 46,01 & es & e & loess & $\mathrm{c}$ & $32-100$ & 9 & 1 & 1,48 & 3 & 3 & 3 & - & - & - & 0 & 9,1 & 0 & 80 & 10 & 70 & 00 & 0 & 0 \\
\hline 5,09 & 45,98 & $\begin{array}{l}\text { Domb } \\
\text { es }\end{array}$ & Saôn & $\begin{array}{l}\text { Dacalcified } \\
\text { loess }\end{array}$ & $\begin{array}{l}\text { TA5- } \\
\mathrm{c}\end{array}$ & $32-100$ & $\begin{array}{l}92,9 \\
3\end{array}$ & $\begin{array}{l}0,4 \\
5\end{array}$ & 2,13 & $\begin{array}{l}0,0 \\
3\end{array}$ & $\begin{array}{l}0,4 \\
9\end{array}$ & $\begin{array}{l}1,1 \\
5\end{array}$ & - & $\begin{array}{l}6,7 \\
0\end{array}$ & - & $\begin{array}{l}7,5 \\
0\end{array}$ & 9,7 & $\begin{array}{l}43,6 \\
0\end{array}$ & $\begin{array}{l}107, \\
90\end{array}$ & $\begin{array}{l}15, \\
20\end{array}$ & $\begin{array}{l}278, \\
40\end{array}$ & $\begin{array}{l}283, \\
10\end{array}$ & $\begin{array}{l}8,4 \\
0\end{array}$ & $\begin{array}{l}2,5 \\
0\end{array}$ \\
\hline 5,22 & 46,00 & $\begin{array}{l}\text { Domb } \\
\text { es } \\
\text { Domb }\end{array}$ & $\begin{array}{l}\text { Saôn } \\
\text { e } \\
\text { Saôn }\end{array}$ & $\begin{array}{l}\text { Dacalcified } \\
\text { loess } \\
\text { Dacalcified }\end{array}$ & $\begin{array}{l}\text { TA7- } \\
\mathrm{c} \\
\text { TB2- }\end{array}$ & $32-100$ & $\begin{array}{l}94,2 \\
2 \\
95,0\end{array}$ & $\begin{array}{l}0,3 \\
3 \\
0,3\end{array}$ & 1,77 & $\begin{array}{l}0,0 \\
1 \\
0,0\end{array}$ & $\begin{array}{l}0,4 \\
3 \\
0,4\end{array}$ & $\begin{array}{l}1,0 \\
7 \\
0,9\end{array}$ & - & $\begin{array}{l}- \\
47\end{array}$ & - & $\begin{array}{l}7,6 \\
0\end{array}$ & - & $\begin{array}{l}44,6 \\
0\end{array}$ & $\begin{array}{l}90,2 \\
0\end{array}$ & $\begin{array}{l}14, \\
40 \\
15\end{array}$ & $\begin{array}{l}361, \\
00 \\
144,\end{array}$ & $\begin{array}{l}299, \\
00\end{array}$ & $\begin{array}{l}8,4 \\
0 \\
11,\end{array}$ & - \\
\hline 4,90 & 46,16 & $\begin{array}{l}\text { es } \\
\text { Domb }\end{array}$ & $\begin{array}{l}\text { e } \\
\text { Saôn }\end{array}$ & $\begin{array}{l}\text { loess } \\
\text { Dacalcified }\end{array}$ & $\begin{array}{l}\mathrm{c} \\
\mathrm{TC} 5-\end{array}$ & $32-100$ & $\begin{array}{l}5 \\
94,6\end{array}$ & $\begin{array}{l}3 \\
0,3\end{array}$ & 1,30 & $\begin{array}{l}1 \\
0,0\end{array}$ & $\begin{array}{l}3 \\
0,4\end{array}$ & $\begin{array}{l}5 \\
0,9\end{array}$ & - & 1 & - & 7 & - & 43 & 91,4 & $\begin{array}{l}6 \\
12\end{array}$ & $\begin{array}{l}6 \\
519\end{array}$ & 278 & 1 & 2,3 \\
\hline 5,11 & 45,90 & es & $\mathrm{e}$ & loess & $\mathrm{c}$ & $32-100$ & 4 & 3 & 1,49 & 3 & 4 & 6 & - & 4 & - & 3,6 & - & 47,4 & 91,4 & 6 & 5 & 455 & 5,1 & 2,6 \\
\hline 4,89 & 44,89 & $\begin{array}{l}\text { Domb } \\
\text { es }\end{array}$ & $\begin{array}{l}\text { Saôn } \\
\text { e }\end{array}$ & $\begin{array}{l}\text { Dacalcified } \\
\text { loess }\end{array}$ & $\begin{array}{l}\text { TD1- } \\
\mathrm{c}\end{array}$ & $32-100$ & $\begin{array}{l}87,1 \\
3\end{array}$ & $\begin{array}{l}0,5 \\
5\end{array}$ & 2,56 & $\begin{array}{l}0,0 \\
9\end{array}$ & $\begin{array}{l}0,6 \\
9\end{array}$ & $\begin{array}{l}1,5 \\
9\end{array}$ & - & $\begin{array}{l}18, \\
8\end{array}$ & - & $\begin{array}{l}11, \\
1\end{array}$ & $\begin{array}{l}11, \\
4\end{array}$ & 59,4 & $\begin{array}{l}121, \\
3\end{array}$ & $\begin{array}{l}19, \\
1\end{array}$ & $\begin{array}{l}263 \\
7\end{array}$ & $\begin{array}{l}171, \\
5\end{array}$ & $\begin{array}{l}11, \\
2\end{array}$ & - \\
\hline 4,78 & 46,05 & $\begin{array}{l}\text { Domb } \\
\text { es }\end{array}$ & $\begin{array}{l}\text { Saôn } \\
\text { e }\end{array}$ & $\begin{array}{l}\text { Dacalcified } \\
\text { loess }\end{array}$ & $\begin{array}{l}\text { TA1- } \\
\text { d }\end{array}$ & $<100$ & $\begin{array}{l}81,3 \\
2\end{array}$ & $\begin{array}{l}0,7 \\
1\end{array}$ & 4,48 & $\begin{array}{l}0,0 \\
4\end{array}$ & $\begin{array}{l}1,9 \\
9\end{array}$ & $\begin{array}{l}1,8 \\
3\end{array}$ & $\begin{array}{l}45,6 \\
2\end{array}$ & $\begin{array}{l}33, \\
35\end{array}$ & $\begin{array}{l}53,2 \\
2\end{array}$ & $\begin{array}{l}11, \\
76\end{array}$ & $\begin{array}{l}20, \\
42\end{array}$ & $\begin{array}{l}98,2 \\
7\end{array}$ & $\begin{array}{l}153, \\
80\end{array}$ & $\begin{array}{l}32 \\
62\end{array}$ & $\begin{array}{l}389, \\
67\end{array}$ & $\begin{array}{l}449, \\
91\end{array}$ & $\begin{array}{l}10, \\
63\end{array}$ & $\begin{array}{l}10, \\
13\end{array}$ \\
\hline 4,90 & 46,01 & $\begin{array}{l}\text { Domb } \\
\text { es }\end{array}$ & $\begin{array}{l}\text { Saôn } \\
\text { e }\end{array}$ & $\begin{array}{l}\text { Dacalcified } \\
\text { loess }\end{array}$ & $\begin{array}{l}\text { TA3- } \\
\text { d }\end{array}$ & $<100$ & $\begin{array}{l}84,4 \\
5\end{array}$ & $\begin{array}{l}0,6 \\
4\end{array}$ & 2,11 & $\begin{array}{l}0,0 \\
2\end{array}$ & $\begin{array}{l}0,5 \\
8\end{array}$ & $\begin{array}{l}0,8 \\
8\end{array}$ & - & $\begin{array}{l}6,7 \\
3\end{array}$ & $\begin{array}{l}25,7 \\
1\end{array}$ & $\begin{array}{l}11, \\
00\end{array}$ & $\begin{array}{l}15, \\
83\end{array}$ & $\begin{array}{l}40,6 \\
7\end{array}$ & $\begin{array}{l}124, \\
67\end{array}$ & $\begin{array}{l}37, \\
32\end{array}$ & $\begin{array}{l}384 \\
74\end{array}$ & $\begin{array}{l}155, \\
54\end{array}$ & $\begin{array}{l}3,1 \\
8\end{array}$ & $\begin{array}{l}6,7 \\
4\end{array}$ \\
\hline 5,09 & 45,98 & $\begin{array}{l}\text { Domb } \\
\text { es }\end{array}$ & $\begin{array}{l}\text { Saôn } \\
\text { e }\end{array}$ & $\begin{array}{l}\text { Dacalcified } \\
\text { loess }\end{array}$ & $\begin{array}{l}\text { TA5- } \\
\text { d }\end{array}$ & $<100$ & $\begin{array}{l}89,7 \\
0\end{array}$ & $\begin{array}{l}0,7 \\
3\end{array}$ & 3,03 & $\begin{array}{l}0,0 \\
3\end{array}$ & $\begin{array}{l}0,5 \\
8\end{array}$ & $\begin{array}{l}1,3 \\
1\end{array}$ & $\begin{array}{l}28,1 \\
8\end{array}$ & $\begin{array}{l}34, \\
95\end{array}$ & $\begin{array}{l}46,0 \\
4\end{array}$ & $\begin{array}{l}8,6 \\
8\end{array}$ & $\begin{array}{l}11, \\
90\end{array}$ & $\begin{array}{l}80,1 \\
2\end{array}$ & $\begin{array}{l}129, \\
62\end{array}$ & $\begin{array}{l}35, \\
19\end{array}$ & $\begin{array}{l}302 \\
09\end{array}$ & $\begin{array}{l}401, \\
08\end{array}$ & $\begin{array}{l}12 \\
57\end{array}$ & $\begin{array}{l}10, \\
13\end{array}$ \\
\hline
\end{tabular}




\begin{tabular}{|c|c|c|c|c|c|c|c|c|c|c|c|c|c|c|c|c|c|c|c|c|c|c|c|c|}
\hline 5,22 & 46,00 & $\begin{array}{l}\text { Domb } \\
\text { es }\end{array}$ & $\begin{array}{l}\text { Saôn } \\
\text { e }\end{array}$ & $\begin{array}{l}\text { Dacalcified } \\
\text { loess }\end{array}$ & $\begin{array}{l}\text { TA7- } \\
\text { d }\end{array}$ & $<100$ & $\begin{array}{l}87,7 \\
8 \\
\end{array}$ & $\begin{array}{l}0,7 \\
0\end{array}$ & 3,90 & $\begin{array}{l}0,0 \\
2\end{array}$ & $\begin{array}{l}0,5 \\
1\end{array}$ & $\begin{array}{l}1,4 \\
2\end{array}$ & $\begin{array}{l}37,8 \\
0\end{array}$ & $\begin{array}{l}43, \\
21\end{array}$ & $\begin{array}{l}49,7 \\
3\end{array}$ & $\begin{array}{l}10, \\
05\end{array}$ & $\begin{array}{l}11, \\
04\end{array}$ & $\begin{array}{l}86,0 \\
3\end{array}$ & $\begin{array}{l}124, \\
52\end{array}$ & $\begin{array}{l}31 \\
30\end{array}$ & $\begin{array}{l}337, \\
95\end{array}$ & $\begin{array}{l}458, \\
35\end{array}$ & $\begin{array}{l}11, \\
96\end{array}$ & $\begin{array}{l}6,7 \\
4\end{array}$ \\
\hline & 6,16 & $\begin{array}{l}\text { Domb } \\
\text { es }\end{array}$ & $\begin{array}{l}\text { Saôn } \\
\text { e }\end{array}$ & $\begin{array}{l}\text { Dacalcified } \\
\text { loess }\end{array}$ & $\begin{array}{l}\text { TB2- } \\
\text { d }\end{array}$ & $<100$ &, 5 & $\begin{array}{l}0,6 \\
8\end{array}$ & 4.59 & $\begin{array}{l}0,0 \\
2\end{array}$ & $\begin{array}{l}0,5 \\
8\end{array}$ & $\begin{array}{l}1,4 \\
4\end{array}$ & $\begin{array}{l}51,2 \\
6\end{array}$ & $\begin{array}{l}47, \\
67\end{array}$ & $\begin{array}{l}60,3 \\
1\end{array}$ & $\begin{array}{l}11, \\
63\end{array}$ & $\begin{array}{l}15, \\
47\end{array}$ & 96,5 & $\begin{array}{l}137, \\
67\end{array}$ & $\begin{array}{l}34, \\
99\end{array}$ & $\begin{array}{l}314, \\
19\end{array}$ & $\begin{array}{l}465, \\
49,\end{array}$ & $\begin{array}{l}12, \\
31\end{array}$ & $\begin{array}{l}11, \\
35\end{array}$ \\
\hline & & Domb & Saôn & Dacalcified & TC5- & & 84,3 & 0,6 & & 0,0 & 0,7 & 1,5 & 65,2 & 35 , & 53,4 & 11 , & 15 , & 93,6 & 137, & 35 , & 3, & 441 , & 6,7 & \\
\hline 5,11 & 45,90 & & e & loess & & $<100$ & & 8 & 5,18 & 4 & 0 & 6 & & 73 & 9 & 44 & 53 & & 27 & 39 & 51 & 81 & & 88 \\
\hline 89 & 44,89 & $\begin{array}{l}\text { Domb } \\
\text { es }\end{array}$ & $\begin{array}{l}\text { Saôn } \\
\text { e }\end{array}$ & $\begin{array}{l}\text { Dacalcified } \\
\text { loess }\end{array}$ & $\begin{array}{l}\text { TD1- } \\
\text { d }\end{array}$ & $<100$ & $\begin{array}{l}78,7 \\
0\end{array}$ & $\begin{array}{l}0,7 \\
0\end{array}$ & 5,71 & $\begin{array}{l}0,1 \\
3\end{array}$ & $\begin{array}{l}0,9 \\
1\end{array}$ & $\begin{array}{l}1,8 \\
4\end{array}$ & $\begin{array}{l}60,9 \\
4\end{array}$ & $\begin{array}{l}51, \\
01\end{array}$ & $\begin{array}{l}70,3 \\
7\end{array}$ & $\begin{array}{l}15, \\
44\end{array}$ & $\begin{array}{l}21, \\
64\end{array}$ & $\begin{array}{l}89,6 \\
3\end{array}$ & $\begin{array}{l}141, \\
93\end{array}$ & $\begin{array}{l}33 \\
36\end{array}$ & $\begin{array}{l}328, \\
66\end{array}$ & $\begin{array}{l}128, \\
09\end{array}$ & $\begin{array}{l}14, \\
95\end{array}$ & $\begin{array}{l}10, \\
40\end{array}$ \\
\hline
\end{tabular}

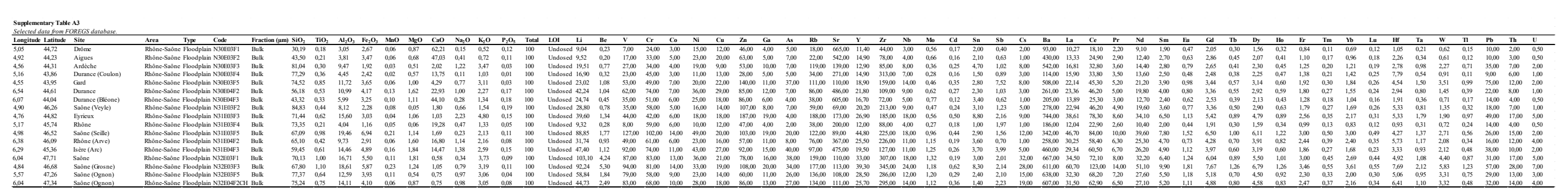

